Discussion Paper No. 16-067

\title{
Emissions Trading and Productivity: Firm-level Evidence from German Manufacturing
}

Benjamin Johannes Lutz

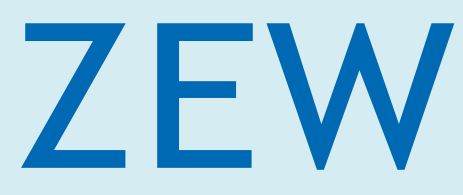

Zentrum für Europäische Wirtschaftsforschung $\mathrm{GmbH}$ Centre for European Economic Research 


\title{
Discussion Paper No. 16-067 \\ Emissions Trading and Productivity: Firm-level Evidence from German Manufacturing
}

\author{
Benjamin Johannes Lutz
}

Download this ZEW Discussion Paper from our ftp server:

http://ftp.zew.de/pub/zew-docs/dp/dp16067.pdf

Die Discussion Papers dienen einer möglichst schnellen Verbreitung von neueren Forschungsarbeiten des ZEW. Die Beiträge liegen in alleiniger Verantwortung der Autoren und stellen nicht notwendigerweise die Meinung des ZEW dar.

Discussion Papers are intended to make results of ZEW research promptly available to other economists in order to encourage discussion and suggestions for revisions. The authors are solely responsible for the contents which do not necessarily represent the opinion of the ZEW. 


\title{
Emissions Trading and Productivity: Firm-level Evidence from German Manufacturing
}

\author{
Benjamin Johannes Lutz* \\ University of Heidelberg and \\ Centre for European Economic Research
}

October 6, 2016

\begin{abstract}
I study the causal effect of the European Union Emissions Trading System (EU ETS) on the productivity of German manufacturing firms. Using administrative firm-level data, I estimate robust production functions for narrowly defined industries. This approach allows for an endogenous dynamic productivity process and corrects for simultaneous changes in input use or productivity after a firm is regulated by the EU ETS. After estimating the firm specific productivity, I employ a difference-in-differences framework in order to identify and quantify the average treatment effect of the EU ETS on the productivity of regulated firms. The results suggest no significant negative effect of the EU ETS on productivity. In contrast, the EU ETS had a positive effect on productivity during the first compliance period. An alternative identification strategy based on a combination of the difference-indifferences framework and nearest neighbor matching supports this finding. A subsample analysis provides evidence that the effect of the EU ETS is heterogeneous across industries.

Keywords: Control of Externalities, Emissions Trading, Robust Production Function Estimation, Productivity, Difference-in-Differences

JEL-Classification: D22, D24, Q52
\end{abstract}

\footnotetext{
${ }^{*}$ Centre for European Economic Research (ZEW), P.O. Box 1034 43, 68034 Mannheim, Germany, Email: lutz@zew.de.
} 


\section{Introduction}

The increased likelihood of disasters linked to climate change, such as floodings, droughts, and forest fires, has put greenhouse gas reduction targets on policy agendas worldwide. The European Union (EU) acknowledged the importance of this endeavor by committing itself to cut greenhouse gas emissions by 20 percent until 2020 compared to 1990 figures. In 2005, the EU introduced the EU Emissions Trading System (EU ETS), a multinational cap-and-trade system, in order to regulate emissions from stationary industrial installations. The need for effective and efficient policy instruments to mitigate greenhouse gas emissions requires a thorough ex post evaluation of existing policies. The analysis of the EU ETS and its impact on regulated firms offers the opportunity to better understand the mechanisms and consequences of market based policy instruments.

First studies investigating the causal effects of the EU ETS show that it significantly reduced carbon dioxide emissions of regulated firms in many countries and spurred the development of new low carbon technologies throughout Europe (Petrick and Wagner, 2014; Wagner, Muûls, Martin, and Colmer, 2014; Klemetsen, Rosendahl, and Jakobsen, 2016; Calel and Dechezleprêtre, 2016). Despite its positive short and long term effects, the EU ETS has been the subject of significant political debate due to its potential adverse impact on the economic performance and competitiveness of regulated fims that compete on global markets.

From a theoretical point of view, it is not clear whether the EU ETS has an overall negative effect on the economic performance of regulated firms. The cost of complying with the EU ETS might decrease revenues and profits. However, according to the induced innovation hypothesis postulated by Hicks (1932), a relative change in input prices might create incentives to invest in new technology in order to reduce the use of the increasingly expensive input. In which way these adjustments affect economic performance depends on the production technolgy, input and output markets, and other factors that differ across firms. Porter (1991) and Porter and van der Linde (1995) put forward a stronger hypothesis specificly addressing the effects of environmental policy. They argue that properly designed regulation might not only increase the incentives to develop and adopt environmentally friendly technology but also consequently might affect competitiveness in a favorable manner.

Calel and Dechezleprêtre (2016) empirically investigate the induced innovation hypothesis and show that the EU ETS has a positive causal impact on low carbon innovation measured by patenting activities. These inventions, but also operational changes or investments in existing more efficient technologies might increase economic performance and create an advantage for regulated firms over competitors.

The aim of this study is to analyze the causal effect of the EU ETS on the economic performance of regulated firms. First, I estimate a structural production function model in order to obtain the total factor productivity as a robust and comprehensive measure of economic performance. Secondly, I isolate and quantify the effect of the EU ETS on the productivity of regulated firms by exploiting treatment variation that results from 
the design of the scheme.

The dispersion in productivity levels across firms and plants has been under investigation in many areas of economic research, such as industrial organization, labor, and trade (Syverson, 2011). Internal factors, such as input quality (Van Biesebroeck, 2003), managerial practice (Bloom and Van Reenen, 2007), or R\&D activity (Doraszelski and Jaumandreu (2013)), but also external factors, such as trade competition (De Loecker, 2007) or market regulation (Knittel, 2002) drive firm-level productivity 1

Furthermore, market based environmental regulation has been identified as a driver of firm-level productivity. Greenstone, List, and Syverson (2012) investigate the impact of air quality regulation on the productivity of U.S. plants. Regulations governing ozone, particulates, and sulfor dioxide decreased productivity, while regulations limiting carbon monoxide increased productivity. On average, the productivity of polluting plants decreased by 4.8 percent in regulated areas. Commins, Lyons, Schiffbauer, and Tol (2011) investigate the correlation between energy taxation and productivity during the period from 1997 to 2007. They use balance sheet data of European firms from the sectors manufacturing, energy, and transport. Exploiting industry level variation in energy taxation, they find a positive correlation between taxation and firm-level productivity. In addition, they report a negative correlation between EU ETS participation and productivity for the first compliance period.

The origins of production function estimation date far back in economic literature. Marschak and Andrews (1944) investigate the challenges of estimating production functions using OLS. The observed input factors that enter the production function are chosen by firms. Therefore, unobserved firm specific determinants of production that are correlated with the choice of inputs are likely to bias OLS estimates. Recent advances have been made by Olley and Pakes (1996) (henceforth OP) who develop a structural econometric model of production that corrects for the described simultaneity bias using investments to proxy unobserved firm specific productivity shocks. Levinsohn and Petrin (2003) (henceforth LP) show that also static inputs can be used as proxies in the framework of the control function approach. Ackerberg, Caves, and Frazer (2015) (henceforth ACF) build on the basic idea to use observed firm characteristics to proxy the unobserved productivity, but suggest a more general and more robust estimation procedure. De Loecker (2013) enhances the ACF model by allowing for an endogenous productivity process.

The empirical strategy of this paper consists of two steps. First, I follow ACF and De Loecker (2013) and estimate a robust production function that allows the EU ETS to simultaneously influence input choice and productivity process in order to obtain an estimate for firm-level productivity. Secondly, I employ an identification strategy that relies on treatment variation caused by the design of the EU ETS in order to estimate the average treatment effect of the EU ETS on the productivity of regulated firms. In order to balance administrative cost, the EU exempts small and medium sized emitters from

\footnotetext{
${ }^{1}$ See Syverson (2011) for a comprehensive survey on the productivity dispersion literature.
} 
regulation by the EU ETS. As a consequence, there are regulated and unregulated firms within narrowly defined industries. I exploit this variation by estimating a variety of difference-in-differences models that isolate the effect of the EU ETS from confounding factors.

The empirical analysis is based on administrative firm data from Germany. I observe detailed annual firm-level information for the period from 1999 to 2012. The core of the dataset is the Cost Structure Survey (henceforth CSS) carried out by the German statistical offices. The CSS contains comprehensive annual information on output produced and inputs used by firms that operate in the manufacturing sector. It is the foundation of many governmental statistics and reports on the activities of the manufacturing sector.

The average treatment effect of the EU ETS on the productivity of regulated firms is statistically significant and ranges between 0.5 and 0.7 percent during the first compliance period depending on the set of control variables. The estimated treatment effect for the second compliance period is negative, but economically and statistically insignificant. Moreover, annual average treatment effects support the finding that the EU ETS had an impact during the first compliance period, while the estimated effects are not significantly different from zero for years of the second compliance period. In order to investigate the heterogeneity of the treatment effect across industries, I additionally estimate the difference-in-differences model for energy intensive two-digit industries with a sufficient number of regulated firms. The effect of the EU ETS on the productivity of firms from the food, paper, and chemical industry are not significantly different from zero. When estimating the model based on data for the industry producing basic metals, I find a significant positive effect for the first compliance period ranging between 2.4 and 2.9 percent.

In order to relax the parametric assumption of the difference-in-differences model, I follow Fowlie, Holland, and Mansur (2012) and combine the difference-in-differences framework with nonparametric nearest neighbor matching. The estimated treatment effects are statistically significant and positive for the first compliance period. In contrast to the parametric approach, the difference-in-differences matching model also provides evidence for a positive effect of the EU ETS during the second compliance period. The estimated treatment effects are slightly higher in comparison to the parametric approach and range between 1.5 and 2.7 percent for the first compliance period and 1.2 and 1.4 percent for the second compliance period, respectively. Annual treatment effect estimates based on the difference-in-differences matching model support the result that the EU ETS had a stronger effect during the first compliance period. For all models and specifications, I investigate pretreatment years and show that the productivity evolves in a parallel fashion across groups.

The structure of this paper is as follows: Section 2 describes the regulatory framework of the EU ETS and gives an overview of the empirical literature concerned with the causal effects of the EU ETS on firms' production and investment decisions. Section 
3 describes the underlying official firm data and some descriptive statistics. Section 4 describes the empirical production function estimation and the difference-in-differences model employed to identify the causal effect of the EU ETS. Section 5 contains the parameter estimates of the empirical production functions and reports the results of the difference-in-differences model. Section 6 provides robustness checks with regard to heterogeneous treatment effects and functional assumptions. Section 7 discusses the results and concludes.

\section{The EU ETS as a natural experiment}

In the framework of the Kyoto Protocol, the EU committed itself to reducing its greenhouse gas emissions by 20 percent until 2020 compared with 1990 levels. In order to achieve its emission targets, the EU decided in 2003 to regulate greenhouse gas emissions from industrial installations by building an EU wide emissions trading system (European Parliament and Council, 2003). The resulting EU ETS was finally introduced in 2005 and currently regulates about 45 percent of the EU's greenhouse gas emissions caused by more than 11,000 installations in 31 countries ${ }^{2}$

The EU ETS covers emissions from combustion installations and installations that run energy intensive production processes, such as oil refining, the production of metals, cement, lime, ceramics, bricks, glass, or paper. The design of the EU ETS excludes small and medium sized installations. For each of the listed processes, the European Commission (EC) defined specific capacity thresholds that determine the inclusion into the EU ETS 3 The regulated installations have to undergo a continuous monitoring, reporting, and verification process. Once a year, they surrender allowances equivivalent to their verified emissions.

The first compliance period of the EU ETS lasted from 2005 to 2007. It served as a pilot phase and was completely decoupled from the following compliance periods. As a consequence, allowances from the pilot phase were not eligible for surrender in later years. In 2005, the allowance price ranged between 20 and 30 euros. The price dropped and finally approached zero in 2007, when market participants realized that there was a massive oversupply on the market. The pilot phase was followed by second compliance period that coincided with the first commitment period of the Kyoto Protocol from 2008 to 2012. After the start of the second compliance period, the prices ranged between 20 and 30 euros, however a massive oversupply of allowances resulted in another price drop during the second half of 2008. As in previous years, the allowances were mostly allocated for free based on historic emissions. The plummeting demand due to the economic crisis and the massive use of project based emission credits from the flexible mechanisms of the Kyoto Protocol did not meet the rather inelastic supply of allowances. The allowance price remained at a level of around 15 euros until a further shift in the second half of

\footnotetext{
${ }^{2}$ The EU ETS operates in the 28 member states of the EU as well as in Iceland, Liechtenstein, and Norway.

${ }^{3}$ See European Parliament and Council (2003) Annex I for details on the inclusion criteria.
} 
2011 when the allowance price dropped below 10 euros. In contrast to 2007, the price did not converge toward zero since the allowances could also be used for compliance in subsequent years $4^{4}$

Regulated firms can comply with the EU ETS in different ways. First, a regulated firm can surrender allowances to legitimate its emissions. This strategy is dominant as long as the allowance price is lower than the cost of abatement. Regardless of how the firm obtains the required allowances, the surrender of allowances negatively affects its economic performance. Alternatively, a regulated firm can abate greenhouse gas emissions through a change in input choice, an adjustment of the production technology, or the development of less emission intensive products. The effect of these abatement options on the firm's economic performance is less clear. A change in input choice, such as a fuel switch, comes at relatively low cost and might not have any additional effects on the firm. An adjustment of the production technology for example through investments in energy efficiency however might not only reduce the use of fuel but could also increase the overall efficiency of the firm. The development of new products also requires investments, but might create an advantage over competitors. From a theoretical perspective, it is not clear whether the EU ETS had a significant negative effect on firm performance or whether secondary effects of abatement measures increased economic performance.

A few very recent studies aim to contribute empirical evidence to the academic and public debates by investigating the causal effects of the EU ETS on the emissions and the economic performance of regulated firms. These studies exploit treatment variation that results from the inclusion criteria of the EU ETS. Since only large emitters are regulated, there are regulated and unregulated firms within narrowly defined industries that can be compared. The empirical evidence on the impact of the EU ETS on firm-level emissions and emission intensity is mixed. Studies using data from Germany, France, and Norway suggest that the EU ETS significantly reduced greenhouse gas emission (Petrick and Wagner, 2014; Wagner, Muûls, Martin, and Colmer, 2014; Klemetsen, Rosendahl, and Jakobsen (2016)) . $^{5}$ Jaraite and Di Maria (2016) do not find that the EU ETS significantly decreased firm-level emissions in Lithuania, but they find a significant negative effect on emission intensity. So far, there is no evidence that the EU ETS had a significant negative effect on indicators of economic performance. In contrast, Petrick and Wagner (2014) find a positive effect of the EU ETS on the revenues of regulated firms in Germany. Klemetsen, Rosendahl, and Jakobsen, 2016 find a positive effect on value added and labor productivity of regulated firms in Norway. Calel and Dechezleprêtre (2016) investigate the effect of the EU ETS on patenting. Their findings support that the EU ETS increased the number of low carbon patents developed by regulated firms. Bushnell, Chong, and Mansur (2013) examine how the EU ETS affects daily stock returns of European firms. They show that low allowance prices are associated with low stock prices for firms in both carbon and electricity intensive industries. Their results

\footnotetext{
${ }^{4}$ See Figure A.1 in Appendix A for details.

${ }^{5}$ Most of the studies investigating the causal effects of the EU ETS are still work under progress and thus not yet peer reviewed.
} 
indicate that regulated firms profit from free allocation of allowances and a potential pass-through of environmental cost. Fabra and Reguant (2014) employ reduced-form and structural estimations in order to measure the pass-through of costs related to the EU ETS. Using Spanish electricity market data, they show that the environmental costs are almost completely passed through to electricity prices.

The aim of this study is to further investigate the impact of the EU ETS on the economic performance of regulated firms. Debates on potential detrimental effects of emissions trading on economic performance have accompanied the first two compliance periods of the EU ETS. Large lobby groups such as the Federation of German Industries frequently point out that the EU ETS imposes high costs on regulated firms and thus threatens the competitiveness of European industries (The Federation of German Industries, 2016) 6 This paper gives nuance to these debates with sound empirical evidence on the causal effects of the EU ETS.

The existing ex post evaluations investigate the effect of the EU ETS on revenues, value added, and labor productivity. These indicators do not provide a comprehensive picture of the firm specific economic performance. I employ a structural production function model in order to obtain a robust estimate of the firm-level total factor productivity. This measure for economic performance has been prominently used in the economic literature to investigate the origins of productivity dispersion.

Following the literature on the ex post evaluation of the EU ETS, I exploit the inclusion criteria of the EU ETS to develop a sound identification strategy. I compare the firm specific productivity of firms that are regulated, i.e. belong to the treatment group, with the productivity of firms that are unregulated, i.e. belong to the control group, before and after the implementation of the EU ETS. I estimate the treatment effect employing parametric and nonparametric difference-in-differences models.

\section{Empirical strategy}

The empirical analysis consists of two subsequent steps.7 First, I estimate a robust production function that allows for an endogenous productivity process. It corrects for simultaneous changes in productivity and input use after a firm is regulated by the EU ETS. The resulting production function is used to recover a firm specific measure of productivity. Secondly, I assess the causal effect of the EU ETS on firm-level productivity by employing the difference-in-differences framework.

\footnotetext{
${ }^{6}$ The Federation of German Industries is an umbrella association representing the interests of more than 100,000 firms with about eight million employees.

${ }^{7}$ I follow the procedure applied by Braguinsky, Ohyama, Okazaki, and Syverson (2015) and employ a two-step approach in order to investigate the effect of the EU ETS on firm specific productivity changes. This procedure enables me to control for a large set of confounding factor in a difference-in-differences framework.
} 


\subsection{Production function estimation}

Since the seminal paper of Marschak and Andrews (1944), it has been known that the estimation of a production function using OLS most likely leads to biased coefficients. The observed input factors that enter the production function - here, capital and labor - are chosen by the firm. If there is a firm specific determinant of production, that influences the input choice and is only visible to the firm itself, the OLS estimates will be biased.

OP develop a structural econometric model of production that corrects for the described simultaneity bias by using investments to proxy unobserved firm specific productivity shocks. LP enhance this approach and show that also static inputs, such as materials or energy use, can be used as proxy variables to control for productivity ${ }^{8} \mathrm{ACF}$ build on the basic idea that underlies OP and LP, namely using observed firm characteristics to proxy the unobserved productivity, but suggest a more general and more robust estimation procedure. I estimate the production function following the approach proposed by ACF.

I assume a Cobb-Douglas production function that takes the following empirical log linear form for firm $i$ at time $t$ :

$$
y_{i t}=\beta_{k} k_{i t}+\beta_{l} l_{i t}+\omega_{i t}+\varepsilon_{i t}
$$

where $y_{i t}$ is the logarithm of gross value added, $k_{i t}$ and $l_{i t}$ denote the observable inputs capital and labor expressed in logs, and $\omega_{i t}$ is the unobservable Hicks neutral productivity term. The error term $\varepsilon_{i t}$ accounts for random shocks and measurement error and is assumed to be identically and independently distributed.

I assume, that the capital stock $k$ at time $t$ is determined by the investment $i$ and the capital stock depreciation in $t-1$. The labor market regulation is quite strict in Germany by granting employees a period of notice that can last several months depending on employment relationship and industry. Therefore, I also treat labor as a dynamic input and assume that it is chosen between $t-1$ and $t$. OP, LP, and ACF assume the dynamics of productivity to evolve according to an exogenous first order Markov process. I follow De Loecker (2013) and consider a more general model, where I allow determinants of production to influence future productivity 9 Accordingly, the evolution

\footnotetext{
${ }^{8}$ Ackerberg, Benkard, Berry, and Pakes (2007) offer a more detailed technical description of the differences between these approaches.

${ }^{9}$ De Loecker (2013) includes exports into the first order Markov process in order to investigate the learning by exporting hypothesis. The idea to allow for endogenous productivity has been implemented in several structural econometric production models. Criscuolo and Martin (2009) examine the productivity of foreign owned plants in the United Kingdom, Doraszelski and Jaumandreu (2013) study the impact of R\&D on productivity and Aw, Roberts, and Xu (2011) develop a structural model to shed light onto the joint impact of investments in R\&D and exporting on productivity dynamics. Collard-Wexler and De Loecker (2015) measure the impact of technology choice on industry wide productivity in the U.S. steel industry. Braguinski, Ohyama, Okazaki, and Syverson (2015) investigate the effect of merger on productivity. All these studies feature the inclusion of additional production determinants into the first order Markov process that governs the productivity dynamics.
} 
of the productivity dynamics is described by

$$
\omega_{i t+1}=f\left(\omega_{i t}, \mathbf{z}_{i t}\right)+\xi_{i t},
$$

where the vector $\mathbf{z}$ collects determinants of production. The EU ETS might influence the production and investment decisions of a regulated firm and thus affect future productivity. Therefore, the effect of the EU ETS on productivity dynamics should be taken into account in order to prevent potential bias. I include a dummy variable indicating if a firm is regulated at time $t$. Furthermore, I add dummies for exports and R\&D, since it has already been shown by De Loecker (2013), Doraszelski and Jaumandreu (2013), and Aw, Roberts, and Xu (2011) that both factors are important drivers of productivity. Accordingly, the functional relationship between $\omega_{i t}$ and the determinants of production is governed by

$$
f\left(\omega_{i t}, \mathbf{z}_{i t}\right)=\sum_{j}^{3} \theta_{j} \omega_{i t}^{j}+\gamma_{1} e t s_{i t}+\gamma_{2} r n d_{i t}+\gamma_{3} \exp _{i t},
$$

where $e t s_{i t}, r n d_{i t}$, and $e x p_{i t}$ denote dummy variables, that indicate if a firm is regulated by the EU ETS, invests in R\&D, or exports, respectively.

In order to deal with correlation between the observed inputs and productivity, I follow LP and rely on a firm's use of intermediate inputs $m$ to control for unobserved productivity shocks that are captured by $\omega_{i t}$. I assume, that a firm's demand for the intermediate input is given by

$$
m_{i t}=g_{t}\left(k_{i t}, l_{i t}, \omega_{i t}, \mathbf{z}_{i t}\right)
$$

I assume monotonicity of intermediate inputs in productivity and thus invert $g_{t}(\cdot)$ to obtain $\omega_{i t}=h_{t}\left(k_{i t}, l_{i t}, m_{i t}, \mathbf{z}_{i t}\right)$, the proxy for productivity in the empirical production function, i.e.

$$
y_{i t}=\beta_{k} k_{i t}+\beta_{l} l_{i t}+h_{t}\left(k_{i t}, l_{i t}, m_{i t}, \mathbf{z}_{i t}\right)+\varepsilon_{i t} .
$$

The parameters $\beta_{k}$ and $\beta_{l}$ are not identified in this equation, since they are both included in $h_{t}(\cdot)$. Following ACF, I non-parametrically estimate this equation to obtain the expected output $E\left[y_{i t} \mid k_{i t}, l_{i t}, m_{i t}, \mathbf{z}_{i t}\right]$. As shown in Equation (6), the disposal of $\varepsilon_{i t}$ enables me to compute the productivity for any possible combination of $\beta_{k}$ and $\beta_{l}$ :

$$
\omega_{i t}\left(\beta_{k}, \beta_{l}\right)=E\left[y_{i t} \mid k_{i t}, l_{i t}, m_{i t}, \mathbf{z}_{i t}\right]-\beta_{k} k_{i t}-\beta_{l} l_{i t} .
$$

As in the ACF approach, I plug $\omega_{i t}\left(\beta_{k}, \beta_{l}\right)$ into the law of motion of productivity in Equation (2) in order to obtain the error term given $\beta_{k}$ and $\beta_{l}, \xi_{i t}\left(\beta_{k}, \beta_{l}\right)$. The consequent moment conditions I employ to identify the parameters of the production function are described by

$$
E\left[\xi_{i t}\left(\beta_{k}, \beta_{l}\right) \mid \begin{array}{c}
k_{i t} \\
l_{i t}
\end{array}\right]=0 .
$$

As explained above, I assume both capital and labor to be dynamic inputs and thus to be mean independent of $\xi_{i t}$. I employ the generalized method of moments to estimate the 
parameters. Finally, I use the estimates for $\beta_{k}$ and $\beta_{l}$ to recover the implied productivity:

$$
\hat{\omega}_{i t}=y-\hat{\beta}_{k} k_{i t}-\hat{\beta}_{l} l_{i t}
$$

\subsection{Disentangling the effect of the EU ETS}

The second step of my empirical analysis is to identify and quantify the causal effect of the EU ETS by comparing changes in productivity across German manufacturing firms that are differentially affected by the EU ETS. Due to the inclusion criteria of the EU ETS, there are regulated and unregulated firms within narrowly defined industries allowing for a natural experiment framework. The baseline specification of the employed difference-in-differences model I estimate for the time period from 1999 to 2012 is

$$
\begin{aligned}
\ln \left(\text { Productivity }_{i t}\right)= & \alpha_{0}+\alpha_{1} \text { ET }_{i}+\alpha_{2} \text { ET }_{i} \times \text { Phase }_{t} \\
& +\alpha_{3} E T S_{i} \times \text { PhaseII }_{t}+\varphi_{s}+\delta_{t}+\lambda_{s t}+u_{i t},
\end{aligned}
$$

where $E T S_{i}$ indicates if a firm is regulated by the EU ETS, Phase $I_{t}$ is equal to one for years during the first compliance period (2005-2007) and zero otherwise, and PhaseII (2008-2012) is equal to one for years during the second compliance period (2008-2012). The inclusion of industry fixed effects $\varphi_{s}$ adjusts for all constant unobserved determinants of productivity across industries. The year fixed effects $\delta_{t}$ control for superior trends in productivity in German manufacturing. $\lambda_{s t}$ denotes the full interaction terms between the industry and year fixed effects and nonparametrically absorbs within industry productivity trends. The error term $u_{i t}$ is assumed to be mean zero.

The parameters $\alpha_{2}$ and $\alpha_{3}$ on the interaction terms between $E T S_{i}$ and the indicators for the two compliance periods Phase $_{t}$ and PhaseII $I_{t}$ are the estimated effect of the EU ETS during Phase I and Phase II, respectively. In order to take into account observed and unobserved heterogeneity across regulated and unregulated firms, I enhance the baseline specification (Specification I) gradually. First, I add additional control variables, namely capital stock, employment, energy use, and material use (Specification II). Then, I add lagged indicators for export and R\&D experience (Specification III) and firm fixed effects that adjust for all constant unobserved determinants of productivity across firms (Specification IV).

Key to the described identification strategy is the parallel trend assumption: I assume that in the absence of regulation by the EU ETS, trends in productivity evolve in a parallel fashion across groups conditional on the included control variables. In order to motivate this assumption, I investigate the development of productivity across treatment and control groups during pretreatment years. In particular, I estimate the following difference-in-differences model for the years before the announcement of the EU ETS, i.e. the period between 1999 and 2002:

$$
\begin{aligned}
\ln \left(\text { Productivity }_{i t}\right)= & \alpha_{0}+\alpha_{1} E T S_{i t}+\alpha_{2} E T S_{i t} \times \mathrm{I}(t>2000) \\
& +\varphi_{s}+\delta_{t}+\lambda_{s t}+u_{i t},
\end{aligned}
$$


where $\mathrm{I}(t>2000)$ equals one for the years 2001 and 2002. Therefore, the parameter $\alpha_{2}$ is a placebo treatment effect. The parallel trend assumption would be violated, if $\alpha_{2}$ is significantly different from zero. I apply this procedure to all aforementioned specifications of the difference-in-differences model.

The model described in Equation 9 provides the average treatment effects of the EU ETS on firm specific productivity for the first and the second compliance period. Within the two compliance periods, there was a high variation in the EUA price. High prices might have provoked stronger reactions by regulated firms and thus might have caused a heterogeneous treatment effect over time. In order to examine, if the effect of the EU ETS on productivity changes over time within the compliance periods, I estimate a modified difference-in-differences model that provides annual treatment effects:

$$
\begin{aligned}
\ln \left(\text { Productivity }_{i t}\right)= & \alpha_{0}+\alpha_{1} E_{T} S_{i t}+\sum_{k=2000}^{2012} \alpha_{k} E T S_{i t} \times \mathrm{I}(t=k) \\
& +\varphi_{s}+\delta_{t}+\lambda_{s t}+u_{i t},
\end{aligned}
$$

where $\mathrm{I}(\mathrm{t}=\mathrm{k})$ is an indicator function associated with the year $t$. The estimated parameters for the years from 2000 to 2004 can be interpreted as placebo treatment effects. They will shed light onto the validity of the underlying assumptions of the difference-indifferences model. If these are significantly different from zero, the model fails to identify the effect of the EU ETS. The estimated parameters for the years from 2005 to 2012 will provide annual average treatment effects. I estimate this modified model applying the same specifications as described above (Specification I - IV).

\section{Data and preliminary analysis}

This study is based on official firm data from Germany. Combining different administrative data sources, I observe detailed annual firm-level information on general characteristics, cost structure, energy use, and EU ETS obligations for the time period from 1999 to 2012.

The core of the dataset is the Cost Structure Survey (CSS) carried out by the Federal Statistical Office and the Statistical Offices of the German Federal States. The CSS contains comprehensive annual information on output produced and inputs employed by firms that operate in the manufacturing sector. The CSS includes all German manufacturing firms with more than 500 employees. For firms with at least 20 and less than 500 employees, the statistical offices collect data from a large random sample. ${ }^{10}$ The participation in the CSS is mandatory by law and results are checked for consistency and verified by the statistical offices. It is the foundation for many governmental statistics and reports on the activities of the manufacturing sector.

\footnotetext{
${ }^{10}$ Similar data sets from other countries have been used in the productivity dispersion literature. Doraszelski and Jaumandreu (2013) for example employ the Spanish equivalent in order to examine the effect of R\&D on firm-level productivity
} 
The random sample of firms with more than 20 and less than 500 employees is renewed once every few years - in the sample period at hand, the random sample has been drawn in 1999, 2003, 2008, and 2012. The random sample is stratified by the number of employees and industry affiliation. Firms with more than 20 and less than 500 employees are always surveyed if they belong to concentrated industries.

In order to add information on employment, exports, investments, and entry and exit to the CSS, I link the CSS with data from the German production census Official Firm Data for Germany (Amtliche Firmendaten für Deutschland - AFiD). The production census is also maintained by the German statistical offices and is obligatory for all manufacturing firms with more than 20 employees. Furthermore, I merge the CSS with the European Union Transaction Log (EUTL) in order to identify firms that are regulated by the EU ETS 11 The resulting unbalanced panel comprises annual data of about 15,000 firms for the years from 1999 to 2012. Due to the dynamic structure of the model, I only consider firms that reported in at least two consecutive years. The industry classification system corresponds to ISIC Revision 4.

The measure for output is the firm's gross value added which is obtained from the CSS and deflated using two-digit ISIC deflators. ${ }^{12}$ The labor input is constructed by taking the annual average of the number of employees reported monthly in the production census. The annual average offers a more detailed view on employment in comparison to the number of employees collected at the reporting date of the CSS. I use detailed investment data contained in the production census in order to compute the capital stock for each firm based on the perpetual inventory method 13 The material expenditures stem from the CSS and are deflated by type using deflators for the manufacturing sector 14 In addition, the firms participating in the CSS are asked to report R\&D expenditures. These comprise the cost of internal $R \& D$ activities, but also joint activities with external research centers and laboratories. I consider a firm to conduct R\&D activities, if the total R\&D expenditures are positive. The production census provides export revenues on the firm-level. Analogously I consider a firm to be exporting if it reports positive export revenues.

In Table 1, I report descriptive statistics to characterize the group of firms regulated by the EU ETS and the group of unregulated firms. Firms regulated by the EU ETS are on average larger in terms of output produced and inputs used. This is due to the design of the EU ETS that only regulates large emitters. There is a relatively high number of small and medium sized firms in the data set. Therefore, statistics on the control group and the entire data set show positively skewed distributions on the main characteristics 15 On average, the firms of the manufacturing sector were expanding

\footnotetext{
${ }^{11}$ See Annex A for more information on the merge of CSS, AFiD, and EUTL.

${ }^{12}$ The data on price indices can be retrieved from the web portal of the Federal Statistical Office: https://www-genesis.destatis.de/genesis/online Producer Price Index 61241-0004.

${ }^{13}$ This procedure has been used by many other papers estimating production functions, as for instance Olley and Pakes (1996). See Annex B for details on the computation of the capital stock.

${ }^{14}$ See footnote 11.

159 in Appendix A reports detailed descriptive statistics on the entire data set showing percentiles and
} 
until the economic crisis led to decreasing demand and contractions in 2009. From 2010 to 2012 , the firms rapidly recovered and continued to grow on average.

Table 1: Descriptive statistics

\begin{tabular}{|c|c|c|c|c|c|c|}
\hline & \multicolumn{3}{|c|}{ EU ETS firms } & \multicolumn{3}{|c|}{ Unregulated firms } \\
\hline & Mean & $\mathrm{SD}$ & $\mathrm{N}$ & Mean & $\mathrm{SD}$ & $\mathrm{N}$ \\
\hline \multicolumn{7}{|l|}{2000} \\
\hline Gross value added (EUR 1000) & 270,956 & 930,476 & 339 & 19,323 & 186,228 & 14,768 \\
\hline Output (EUR 1000) & 623,951 & $2,348,248$ & 338 & 45,760 & 415,962 & 14,660 \\
\hline Capital stock (EUR 1000) & 277,470 & 851,531 & 339 & 15,825 & 117,142 & 14,700 \\
\hline Energy use (MWh) & $1,139,299$ & $4,880,839$ & 339 & 21,816 & 293,735 & 14,767 \\
\hline Number of employees & 2,339 & 8,429 & 339 & 248 & 1,661 & 14,767 \\
\hline R\&D expenditure (EUR 1000) & 35,334 & 215,372 & 339 & 1,636 & 41,329 & 14,768 \\
\hline Exports (EUR 1000) & 417,213 & $2,165,096$ & 339 & 21,343 & 324,984 & 14,767 \\
\hline \multicolumn{7}{|l|}{2005} \\
\hline Gross value added (EUR 1000) & 296,848 & $1,173,846$ & 383 & 19,685 & 178,177 & 13,475 \\
\hline Output (EUR 1000) & 711,907 & $2,778,015$ & 381 & 50,103 & 443,246 & 13,223 \\
\hline Capital stock (EUR 1000) & 278,734 & 930,450 & 383 & 16,143 & 117,655 & 13,389 \\
\hline Energy use (MWh) & $1,291,501$ & $4,469,597$ & 383 & 19,937 & 169,754 & 13,286 \\
\hline Number of employees & 2,260 & 8,013 & 383 & 241 & 1,622 & 13,474 \\
\hline R\&D expenditure (EUR 1000) & 44,205 & 253,976 & 383 & 1,913 & 45,681 & 13,475 \\
\hline Exports (EUR 1000) & 503,908 & $2,511,781$ & 383 & 26,790 & 370,656 & 13,474 \\
\hline \multicolumn{7}{|l|}{2010} \\
\hline Gross value added (EUR 1000) & 270,600 & $1,050,857$ & 440 & 18,274 & 201,533 & 14,959 \\
\hline Output (EUR 1000) & 696,410 & $3,015,317$ & 438 & 47,815 & 487,422 & 14,812 \\
\hline Capital stock (EUR 1000) & 254,298 & 814,679 & 440 & 14,310 & 109,372 & 14,884 \\
\hline Energy use (MWh) & $1,595,464$ & $6,518,306$ & 440 & 17,217 & 131,277 & 14,818 \\
\hline Number of employees & 1,936 & 7,032 & 440 & 220 & 1,460 & 14,944 \\
\hline R\&D expenditure (EUR 1000) & 42,431 & 258,910 & 440 & 1,715 & 41,345 & 14,959 \\
\hline Exports (EUR 1000) & 540,497 & $3,056,996$ & 440 & 26,037 & 372,078 & 14,945 \\
\hline
\end{tabular}

Notes: Gross value added, output (production value), wages and salaries, R\&D expenditure, exports and capital stock are denoted in EUR 1000. Energy use is denoted in MWh. Source: Research Data Centres of the Statistical Offices Germany (2014): Official Firm Data for Germany (AFiD) - Cost Structure Survey, AFiD-Panel Industrial Units, and AFiD-Module Use of Energy, own calculations.

Table 2 shows the distribution of regulated and unregulated firms across two-digit industries in the merged data set. While combustion installations that generate heat or power can be found in most industries, the firms that operate process regulated installations are mainly concentrated in the industries manufacturing food (10), beverages (11), paper (17), coke and refined petroleum products (19), chemicals (20), pharmaceutical products (21), rubber and plastic (22), other nonmetallic mineral products (23), and basic metals (24).

higher moments of the distributions. 
Table 2: Number of observations by industry: total and regulated firms

\begin{tabular}{|c|c|c|c|c|c|c|c|}
\hline \multirow[b]{2}{*}{ NACE } & \multirow[b]{2}{*}{ Industry } & \multicolumn{2}{|c|}{2005} & \multicolumn{2}{|c|}{2008} & \multicolumn{2}{|c|}{2012} \\
\hline & & Total & Regulated & Total & Regulated & Total & Regulated \\
\hline 10 & Food products & 1,528 & 44 & 1,903 & 52 & 1,888 & 53 \\
\hline 11 & Beverages & 285 & 8 & 260 & 10 & 245 & 11 \\
\hline 12 & Tobacco products & 22 & 1 & 21 & 2 & 21 & 2 \\
\hline 13 & Textiles & 424 & 5 & 414 & 7 & 333 & 4 \\
\hline 14 & Wearing apparel & 268 & 0 & 215 & 0 & 185 & 0 \\
\hline 15 & Leather and related products & 118 & 0 & 103 & 0 & 84 & 0 \\
\hline 16 & Wood and products of wood and cork & 361 & 11 & 458 & 19 & 377 & 16 \\
\hline 17 & Paper and paper products & 359 & 63 & 435 & 72 & 435 & 78 \\
\hline 18 & Printing and reproduction of recorded media & 330 & 2 & 359 & 1 & 329 & 3 \\
\hline 19 & Coke and refined petroleum products & 44 & 15 & 47 & 17 & 45 & 16 \\
\hline 20 & Chemicals and chemical products & 729 & 49 & 854 & 56 & 846 & 54 \\
\hline 21 & Pharmaceutical products & 184 & 8 & 201 & 8 & 185 & 6 \\
\hline 22 & Rubber and plastic products & 806 & 10 & 978 & 9 & 812 & 14 \\
\hline 23 & Other nonmetallic mineral products & 733 & 100 & 792 & 117 & 687 & 119 \\
\hline 24 & Basic metals & 545 & 32 & 642 & 32 & 646 & 35 \\
\hline 25 & Fabricated metal products & 1,522 & 2 & 2,149 & 4 & 1,907 & 2 \\
\hline 26 & Computer, electronic and optical products & 694 & 5 & 831 & 4 & 694 & 4 \\
\hline 27 & Electrical equipment & 808 & 4 & 970 & 4 & 980 & 4 \\
\hline 28 & Machinery and equipment n.e.c. & 2,226 & 6 & 2,585 & 8 & 2,138 & 7 \\
\hline 29 & Motor vehicles, trailers, and semitrailers & 663 & 10 & 701 & 9 & 541 & 9 \\
\hline 30 & Other transport equipment & 257 & 5 & 238 & 5 & 212 & 5 \\
\hline 31 & Furniture & 382 & 0 & 397 & 0 & 351 & 0 \\
\hline 32 & Other manufacturing & 452 & 3 & 587 & 3 & 547 & 2 \\
\hline 33 & Repair and installation of mach. and equip. & 118 & 0 & 108 & 0 & 623 & 1 \\
\hline- & Total & 13,858 & 383 & 16,248 & 439 & 15,111 & 445 \\
\hline
\end{tabular}

Notes: Number of firms for the first year of Phase I of the EU ETS (2005), the first year of Phase II (2008) and the last year of Phase II (2012) that is also the last year I observe. Source: Research Data Centres of the Statistical Offices Germany (2014): Official Firm Data for Germany (AFiD) - Cost Structure Survey and AFiD-Panel Industrial Units, own calculations. 


\section{Results}

In this section, I first report the production function estimates based on the ACF approach I described in Section 3.1. Secondly, I will show the results of the difference-indifferences model I outlined in Section 3.2 in order to shed light onto the causal effect of the EU ETS on firm-level productivity.

\subsection{Production function estimates}

I estimate value added production functions for two-digit industries within manufacturing using data for the time period from 1999 to 2012. Table 3 reports the results of the ACF model along with estimates based on standard OLS regressions, the total number of firms and the total number of observations for the entire sample period.

Table 3: Output elasticities

\begin{tabular}{|c|c|c|c|c|c|c|c|}
\hline \multirow[b]{2}{*}{ NACE } & \multirow[b]{2}{*}{ Industry } & \multirow[b]{2}{*}{ \# Firms } & \multirow[b]{2}{*}{ \# Observ. } & \multicolumn{2}{|c|}{ OLS estimates } & \multicolumn{2}{|c|}{ ACF estimates } \\
\hline & & & & Capital & Labor & Capital & Labor \\
\hline 10 & Food products & 4,342 & 22,981 & $\begin{array}{c}0.349 \\
(0.004)\end{array}$ & $\begin{array}{l}0.643 \\
(0.005)\end{array}$ & $\begin{array}{c}0.369 \\
(0.024)\end{array}$ & $\begin{array}{c}0.541 \\
(0.015)\end{array}$ \\
\hline 11 & Beverages & 664 & 3,889 & $\begin{array}{c}0.137 \\
(0.013)\end{array}$ & $\begin{array}{l}0.985 \\
(0.020)\end{array}$ & $\begin{array}{c}0.181 \\
(0.065)\end{array}$ & $\begin{array}{l}0.949 \\
(0.044)\end{array}$ \\
\hline 13 & Textile & 1,089 & 6,030 & $\begin{array}{c}0.183 \\
(0.006)\end{array}$ & $\begin{array}{c}0.885 \\
(0.010)\end{array}$ & $\begin{array}{c}0.195 \\
(0.022)\end{array}$ & $\begin{array}{c}0.867 \\
(0.038)\end{array}$ \\
\hline 15 & $\begin{array}{l}\text { Leather and related } \\
\text { products }\end{array}$ & 253 & 1,582 & $\begin{array}{c}0.249 \\
(0.012)\end{array}$ & $\begin{array}{c}0.834 \\
(0.019)\end{array}$ & $\begin{array}{l}0.237 \\
(0.035)\end{array}$ & $\begin{array}{c}0.839 \\
(0.055)\end{array}$ \\
\hline 16 & $\begin{array}{l}\text { Wood and products of } \\
\text { wood and cork }\end{array}$ & 1,261 & 5,640 & $\begin{array}{c}0.175 \\
(0.006)\end{array}$ & $\begin{array}{l}0.884 \\
(0.010)\end{array}$ & $\begin{array}{l}0.180 \\
(0.028)\end{array}$ & $\begin{array}{c}0.844 \\
(0.038)\end{array}$ \\
\hline 17 & Paper and paper products & 1,017 & 5,532 & $\begin{array}{c}0.214 \\
(0.007)\end{array}$ & $\begin{array}{c}0.867 \\
(0.010)\end{array}$ & $\begin{array}{l}0.289 \\
(0.034)\end{array}$ & $\begin{array}{l}0.788 \\
(0.052)\end{array}$ \\
\hline 18 & $\begin{array}{l}\text { Printing and reproduction of } \\
\text { recorded media }\end{array}$ & 1,207 & 4,704 & $\begin{array}{c}0.152 \\
(0.007)\end{array}$ & $\begin{array}{c}0.900 \\
(0.010)\end{array}$ & $\begin{array}{l}0.257 \\
(0.087)\end{array}$ & $\begin{array}{c}0.613 \\
(0.196)\end{array}$ \\
\hline 20 & $\begin{array}{l}\text { Chemicals and chemical } \\
\text { products }\end{array}$ & 1,707 & 10,311 & $\begin{array}{c}0.241 \\
(0.006)\end{array}$ & $\begin{array}{c}0.820 \\
(0.008)\end{array}$ & $\begin{array}{l}0.258 \\
(0.024)\end{array}$ & $\begin{array}{c}0.779 \\
(0.039)\end{array}$ \\
\hline 22 & Rubber and plastic products & 2,652 & 11,864 & $\begin{array}{c}0.183 \\
(0.004)\end{array}$ & $\begin{array}{c}0.881 \\
(0.006)\end{array}$ & $\begin{array}{l}0.198 \\
(0.014)\end{array}$ & $\begin{array}{c}0.865 \\
(0.020)\end{array}$ \\
\hline 23 & $\begin{array}{l}\text { Other nonmetallic } \\
\text { mineral products }\end{array}$ & 2,061 & 10,836 & $\begin{array}{l}0.249 \\
(0.005)\end{array}$ & $\begin{array}{c}0.792 \\
(0.007)\end{array}$ & $\begin{array}{l}0.225 \\
(0.016)\end{array}$ & $\begin{array}{c}0.820 \\
(0.019)\end{array}$ \\
\hline 24 & Basic metals & 1,269 & 8,088 & $\begin{array}{l}0.176 \\
(0.006)\end{array}$ & $\begin{array}{l}0.868 \\
(0.009)\end{array}$ & $\begin{array}{l}0.190 \\
(0.026)\end{array}$ & $\begin{array}{c}0.855 \\
(0.036)\end{array}$ \\
\hline 25 & $\begin{array}{l}\text { Fabricated metal } \\
\text { products }\end{array}$ & 5,791 & 24,835 & $\begin{array}{l}0.148 \\
(0.003)\end{array}$ & $\begin{array}{l}0.926 \\
(0.004)\end{array}$ & $\begin{array}{c}0.144 \\
(0.008)\end{array}$ & $\begin{array}{c}0.925 \\
(0.013)\end{array}$ \\
\hline 27 & Electrical equipment & 2,610 & 11,807 & $\begin{array}{c}0.161 \\
(0.005)\end{array}$ & $\begin{array}{c}0.909 \\
(0.007)\end{array}$ & $\begin{array}{c}0.209 \\
(0.054)\end{array}$ & $\begin{array}{c}0.834 \\
(0.079)\end{array}$ \\
\hline 28 & $\begin{array}{l}\text { Machinery and } \\
\text { equipment n.e.c. }\end{array}$ & 6,760 & 31,085 & $\begin{array}{l}0.092 \\
(0.003)\end{array}$ & $\begin{array}{l}0.994 \\
(0.004)\end{array}$ & $\begin{array}{c}0.091 \\
(0.007)\end{array}$ & $\begin{array}{c}0.988 \\
(0.010)\end{array}$ \\
\hline 29 & $\begin{array}{l}\text { Motor vehicles, trailers, } \\
\text { and semitrailers }\end{array}$ & 1,553 & 8,451 & $\begin{array}{c}0.164 \\
(0.006)\end{array}$ & $\begin{array}{c}0.897 \\
(0.008)\end{array}$ & $\begin{array}{c}0.164 \\
(0.006)\end{array}$ & $\begin{array}{c}0.886 \\
(0.023)\end{array}$ \\
\hline 31 & Furniture & 1,256 & 5,544 & $\begin{array}{l}0.156 \\
(0.006) \\
\end{array}$ & $\begin{array}{c}0.927 \\
(0.009) \\
\end{array}$ & $\begin{array}{l}0.168 \\
(0.050)\end{array}$ & $\begin{array}{c}0.853 \\
(0.089) \\
\end{array}$ \\
\hline
\end{tabular}

Notes: All parameter estimates are significant at the $5 \%$ level. Standard errors are computed by employing the block bootstrap Statistical Offices Germany (2014): Official Firm Data for Germany (AFiD) - Cost Structure Survey and AFiD-Panel Industrial Units own calculations. 
The ACF model is implemented employing the general method of moments procedure shown in Section 3.1. The standard errors are clustered at the firm-level and obtained by applying the block bootstrap treating each set of firm observations together as an independent and identical draw from the population of firms ${ }^{16}$ The block bootstrap takes into account that the multiple observations of a firm are correlated over time in some unknown way and corrects for the two-step nature of the general method of moments estimator.

The number of firms within the industries ranges between 253 (leather and related products) and 6,760 (machinery and equipment) firms during the sample period from 1999 to 2012, while the total number of observations ranges between 1,582 (leather and related products) and 31,085 (machinery and equipment). The precision of the estimates tends to increase with the number of observations. All estimated coefficients of the ACF model are statistically significant at conventional levels.

The production functions vary significantly across industries reflecting the heterogeneity within the manufacturing sector. All industries have in common that the coefficient on labor is larger than the coefficient on capital. A comparison of the ACF and the OLS parameters shows that for most industries, the ACF coefficient on capital is larger, while the ACF coefficient on labor is smaller. This is in line with the findings of OP and LP. They show that the endogeneity of the input choice results in an upward or downward bias depending on how fast a firm can adjust the input use. OLS coefficients on relatively inflexible inputs such as capital tend to be biased towards zero, while coefficients on relatively flexible inputs are positively biased. The returns to scale range from 0.87 (printing and reproduction of recorded media) to 1.13 (beverages).

I compute the firm-level productivity as the residual from the production function as described in Equation 8. Figure 1 shows the indexed mean productivity for twodigit industries within manufacturing. The mean productivity evolves quite differently over time across two-digit industries again reflecting the heterogeneity across industries within manufacturing. While some industries record increasing mean productivity (e.g. food products, electrical equipment, machinery and equipment, and motor vehicles, trailers, and semitrailers), others show decreasing mean productivity (e.g. printing and reproduction of recorded media and basic metals, and furniture).

The economic crisis did not affect manufacturing in Germany as seriously as in other European countries. However, demand for German goods decreased significantly in 2009. This development is also reflected in a drop in productivity of most two-digit industries. Firms cannot smoothly adapt their input choice to demand shocks. Therefore, a rapid decline in demand decreases capacity utilization and consequently productivity.

The different developments in productivity across industries are taken into account in the second stage of my empirical analysis. The various specifications of the difference-

\footnotetext{
${ }^{16}$ This approach has been first proposed by LP in this context. Subsequent studies that apply LP or ACF follow this strategy, see e.g. De Loecker and Warzinski (2012), De Loecker (2013), and CollardWexler and De Loecker (2015). More information on the bootstrap can be found in Horowitz (2001)
} 
in-differences model always include industry and year fixed effects as well as a full set of interaction terms. In this way, the model nonparametrically captures heterogeneous developments in productivity across industries and over time.

Figure 1: Indexed mean productivity (base year 1999).
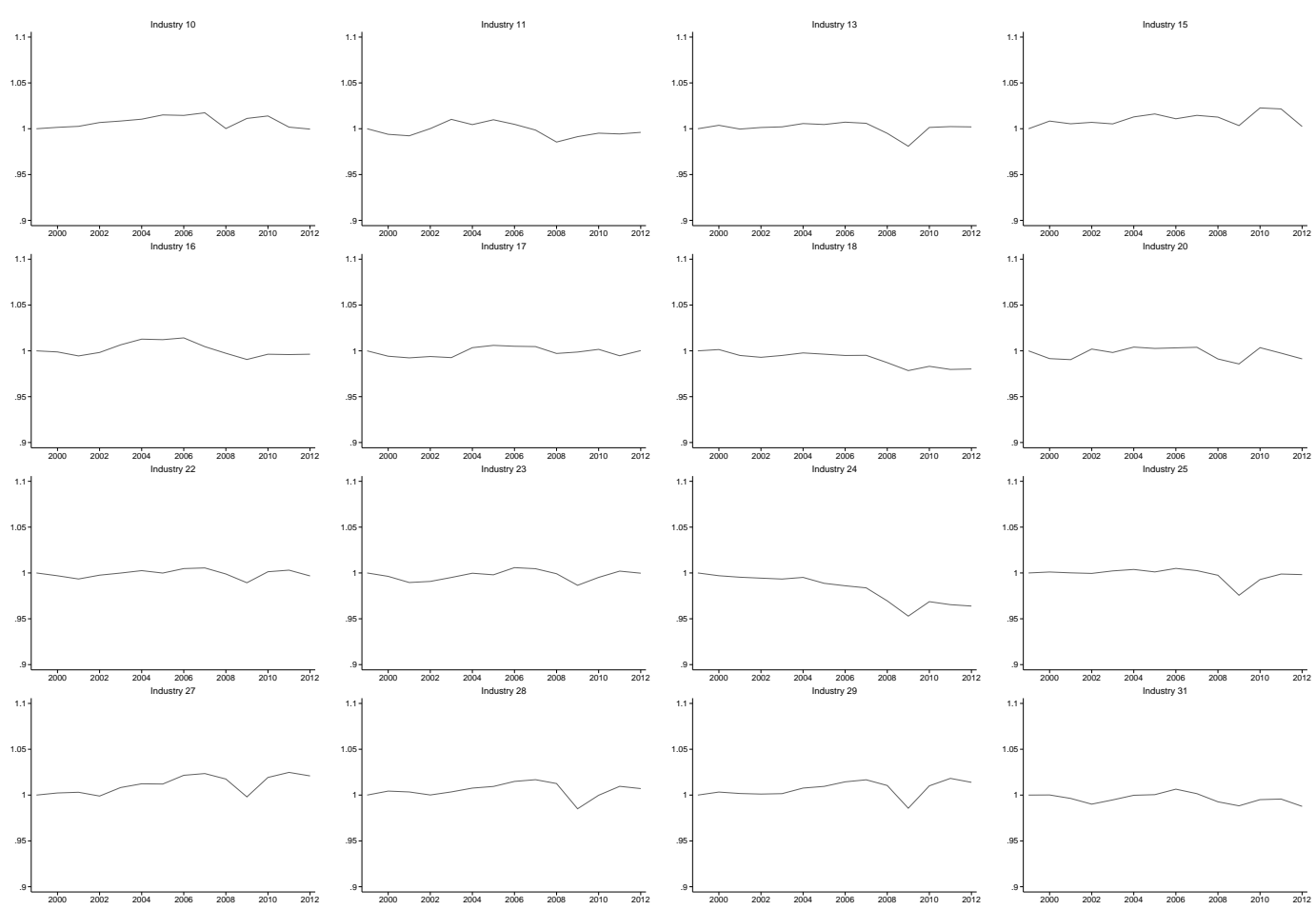

Notes: Source: Research Data Centres of the Statistical Offices Germany (2014): Official Firm Data for Germany (AFiD) - Cost Structure Survey and AFiD-Panel Industrial Units, own calculations. 


\subsection{Estimated treatment effects}

Table 4 reports the results of the difference-in-differences model described in Section 3.2 The first column shows the estimates of Specification I that includes fixed effects and full interaction terms on industry and year. Columns two and three report the results for Specification II and Specification III that include an enhanced set of control variables. The results of Specification IV that adds firm fixed effects are shown in the last column. The displayed treatment effects can be interpreted as semi-elasticities.

Table 4: Difference-in-differences treatment effects.

\begin{tabular}{|c|c|c|c|c|}
\hline & I & II & III & IV \\
\hline Phase I & $\begin{array}{c}0.007^{* *} \\
(0.003)\end{array}$ & $\begin{array}{l}0.005^{*} \\
(0.003)\end{array}$ & $\begin{array}{c}0.005 \\
(0.003)\end{array}$ & $\begin{array}{c}0.007^{* *} \\
(0.003)\end{array}$ \\
\hline Phase II & $\begin{array}{l}-0.000 \\
(0.003)\end{array}$ & $\begin{array}{l}-0.002 \\
(0.003)\end{array}$ & $\begin{array}{l}-0.001 \\
(0.003)\end{array}$ & $\begin{array}{l}-0.001 \\
(0.003)\end{array}$ \\
\hline $\begin{array}{l}\text { Pretreatment } \\
\text { analysis }\end{array}$ & $\begin{array}{c}0.005 \\
(0.003)\end{array}$ & $\begin{array}{c}0.004 \\
(0.003)\end{array}$ & $\begin{array}{l}0.005 \\
(0.003)\end{array}$ & $\begin{array}{c}(0.004) \\
(0.003\end{array}$ \\
\hline \multicolumn{5}{|l|}{ Fixed effects } \\
\hline Industry & $x$ & $\times$ & $x$ & \\
\hline Year & $x$ & $x$ & $x$ & $x$ \\
\hline $\begin{array}{l}\text { Industry year inter- } \\
\text { action terms }\end{array}$ & $x$ & $x$ & $x$ & $x$ \\
\hline Firm & & & & $x$ \\
\hline \multicolumn{5}{|l|}{ Additional controls } \\
\hline $\begin{array}{l}\text { Capital, labor, en- } \\
\text { ergy use, and materials }\end{array}$ & & $x$ & $x$ & $x$ \\
\hline $\begin{array}{l}\text { Indicator for export } \\
\text { and RnD experience }\end{array}$ & & & $x$ & $x$ \\
\hline $\begin{array}{l}\text { \# Firms } \\
(1999-2012)\end{array}$ & 34,373 & 34,215 & 32,302 & 32,302 \\
\hline $\begin{array}{l}\text { \# Observations } \\
(1999-2012)\end{array}$ & 173,178 & 172,065 & 153,823 & 153,823 \\
\hline
\end{tabular}

Notes: Standard errors are computed by employing the block bootstrap algorithm with 500 replications. *** denotes significance at the 99 percent level. ** denotes significance at the 95 percent level. * ${ }^{*}$ denotes significance at the 90 percent level. Source: Research Data Centres of the Statistical Offices Germany (2014): Official Firm Data for Germany (AFiD) - Cost Structure Survey, AFiD-Panel Industrial Units, and AFiD-Module Use of Energy, own calculations.

Bertrand, Duflo, and Mullainathan (2004) point out that conventional standard errors for difference-in-differences applications with long time series and a high serial correlation in the outcome variable are inconsistent. Since the considered time series is rather long (14 years) and productivity is highly persistent, I refrain from applying conventional standard errors. According to Bertrand, Duflo, and Mullainathan (2004) the bootstrap performs well if the cross section is sufficiently large and the serial correlation in the data is taken into account. I follow their recommendation and employ the block bootstrap in order to obtain adequate standard errors for the estimated treatment effects clustered at the firm-level.

Specifications I, II, and IV show a significant positive effect of the EU ETS on 
firm-level productivity ranging between 0.5 and 0.7 percent during the first compliance period. The estimated treatment effects for the second compliance periods are negative, but rather small and statistically insignificant. In order to examine the parallel trend assumption, I estimate the four specifications for the pretreatment time period from 1999 to 2002 treating 2001 as the implementation year of the EU ETS. The results of the pretreatment analysis are report in the third row of Table 4. None of the estimated placebo effects is statistically significant. Consequently, I fail to reject the hypothesis that the key identifying assumption holds strongly supporting the validity of the difference-in-differences approach in this setting.

In addition to the average treatment effect for the entire compliance period, I also estimate the annual effects of the EU ETS as shown in Equation 11 in order to investigate variations in the impact over time. Figure 2 displays the results of the annual treatment effects model. The horizontal line denotes the treatment effect while the horizontal bar denotes the twofold standard deviation. Per year, four bars are shown corresponding to the four specifications outlined above. Most estimated treatment effects are statistically insignificant. However, the annual treatment effects of Phase I are slightly higher in comparison to the pretreatment and Phase II years.

Figure 2: Annual treatment effects.

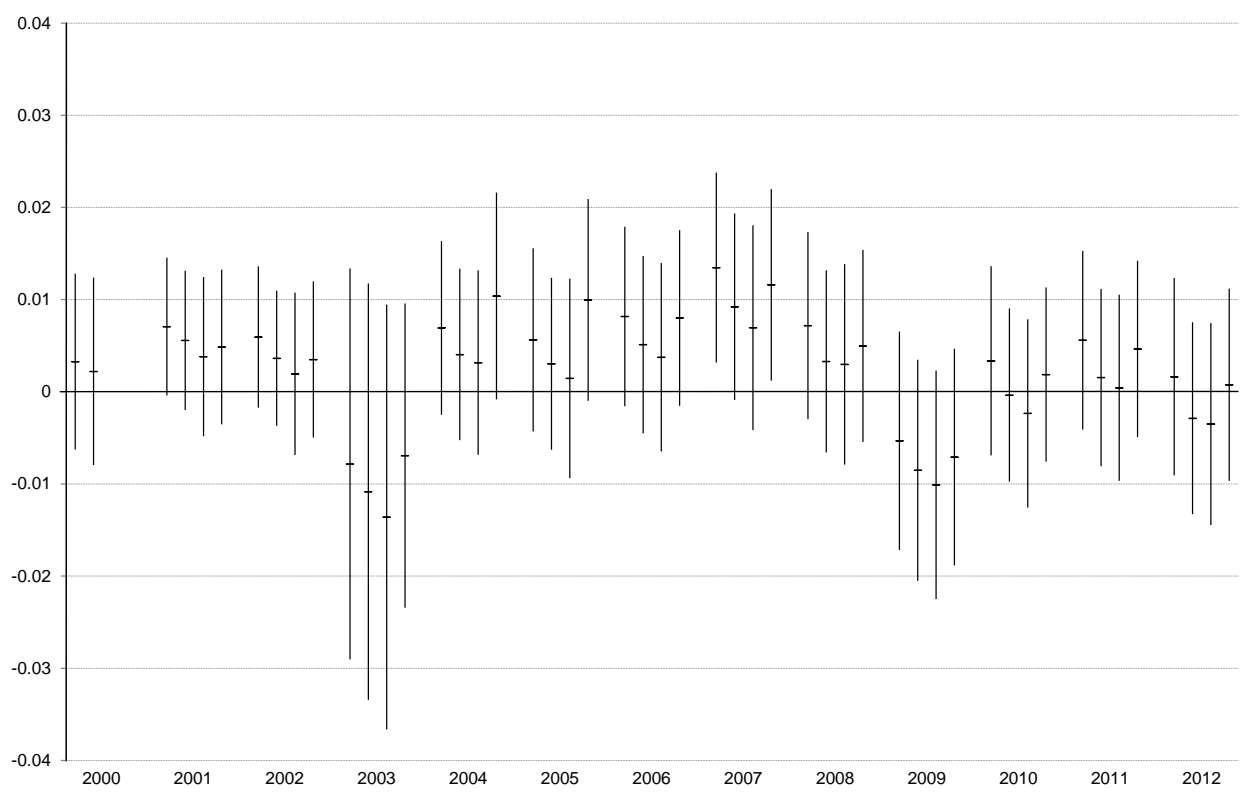

Notes: Annual treatment effects and confidence bands (2 times standard error) for Specification I - Specification IV. Specification III and Specification IV can only be estimated for the period from 2000 to 2012. I employ block bootstrap to obtain standard errors. Source: Research Data Centres of the Statistical Offices Germany (2014): Official Firm Data for Germany (AFiD) - Cost Structure Survey and AFiD-Panel Industrial Units, own calculations. 


\section{Robustness checks}

\subsection{Heterogeneous treatment effects}

The industries within the manufacturing sector differ with regard to many aspects. They produce very different goods, face different market conditions on input and output markets and face different kinds of regulation. As a consequence, the effect of the EU ETS on the regulated firms might vary across industries. The average treatment effect over all industries therefore does not provide the full picture of the impact of the EU ETS.

For this reason, I analyze the effect of the EU ETS at the two-digit industry level. I focus on the industries manufacturing food products (10), paper and paper products (17), chemicals and chemical products (20), rubber and plastic products (22), other nonmetallic mineral products (23) as well as basic metals (24). These industries provide a sufficient number of observations in the group of the regulated firms (see Table 2). I estimate the difference-in-differences model depicted in Equation 9 and further investigate the validity of the parallel trend assumption by estimating a placebo treatment effect during the pretreatment period from 1999 to 2002 as described by Equation 10. The standard errors are again obtained by applying the block bootstrap algorithm.

Table 5 reports the results for Specification I and II and Table 6 shows the results for Specification III and IV, respectively. Considering the first compliance period, the estimated treatment effects for the industries manufacturing food (10), paper (17), and chemicals (20) are mostly positive, but statistically insignificant. During the second compliance period, the effect of the EU ETS was statistically insignificant, but the signs varied across the three industries. The estimated treatment effect was positive for the industries producing food (10) and chemicals (20), while the effect was negative for the paper industry (17). The results for the industries producing rubber and plastic (22) and other nonmetallic mineral products (23) indicate that the parallel trend assumption is violated for some specifications. Therefore, I refrain from interpreting the results for these industries. The EU ETS had a significant positive effect on the firms of the industry producing basic metals (24) during the first compliance period. The effect ranges between 2.4 and 2.9 percent. During the second compliance period, the EU ETS did not significantly influence the productivity of the regulated firms. For this industry, the pretreatment analysis supports the parallel trend assumption.

The subsample analysis sheds light on the heterogeneity of the treatment effect, however, this empirical strategy comes along with a reduction of the sample size. The number of firms ranges from 1,707 (paper industry, 17) to 4,342 (food industry, 10) in the period from 1999 to 2012, while the total number of observation ranges from 10,310 (paper industry, 17) to 22,981 (food industry, 10). As a consequence, the precision of the estimates decreases in comparison to the analysis using the full sample.

The results of the subsample analysis support the hypothesis that the effect of the EU ETS is not homogeneous across industries. 
Table 5: Difference-in-differences treatment effects - subsample analysis (I/II).

\begin{tabular}{|c|c|c|c|c|c|c|c|}
\hline \multirow[b]{2}{*}{ NACE } & \multirow[b]{2}{*}{ Industry } & \multicolumn{3}{|c|}{ I } & \multicolumn{3}{|c|}{ II } \\
\hline & & $\begin{array}{c}\text { Pre- } \\
\text { treatment }\end{array}$ & Phase I & Phase II & $\begin{array}{c}\text { Pre- } \\
\text { treatment }\end{array}$ & Phase I & Phase II \\
\hline 10 & $\begin{array}{l}\text { Food prod- } \\
\text { ucts }\end{array}$ & $\begin{array}{c}0.019 \\
(0.017)\end{array}$ & $\begin{array}{c}0.002 \\
(0.009)\end{array}$ & $\begin{array}{c}0.002 \\
(0.010)\end{array}$ & $\begin{array}{c}0.019 \\
(0.018)\end{array}$ & $\begin{array}{c}0.001 \\
(0.009)\end{array}$ & $\begin{array}{c}0.003 \\
(0.010)\end{array}$ \\
\hline 17 & $\begin{array}{l}\text { Paper and pa- } \\
\text { per products }\end{array}$ & $\begin{array}{l}0.013 \\
(0.010)\end{array}$ & $\begin{array}{c}0.009 \\
(0.012)\end{array}$ & $\begin{array}{l}-0.004 \\
(0.013)\end{array}$ & $\begin{array}{l}0.014 \\
(0.010)\end{array}$ & $\begin{array}{l}0.008 \\
(0.012)\end{array}$ & $\begin{array}{l}-0.005 \\
(0.013)\end{array}$ \\
\hline 20 & $\begin{array}{l}\text { Chemicals and } \\
\text { chemical } \\
\text { products }\end{array}$ & $\begin{array}{l}-0.001 \\
(0.005)\end{array}$ & $\begin{array}{c}0.002 \\
(0.007)\end{array}$ & $\begin{array}{c}0.007 \\
(0.007)\end{array}$ & $\begin{array}{l}-0.001 \\
(0.005)\end{array}$ & $\begin{array}{c}0.002 \\
(0.006)\end{array}$ & $\begin{array}{c}0.005 \\
(0.006)\end{array}$ \\
\hline 22 & $\begin{array}{l}\text { Rubber and } \\
\text { plastic prod- } \\
\text { ucts }\end{array}$ & $\begin{array}{c}0.002 \\
(0.007)\end{array}$ & $\begin{array}{c}0.005 \\
(0.005)\end{array}$ & $\begin{array}{l}0.011^{*} \\
(0.006)\end{array}$ & $\begin{array}{c}0.014 \\
(0.010)\end{array}$ & $\begin{array}{c}0.001 \\
(0.006)\end{array}$ & $\begin{array}{c}0.007 \\
(0.005)\end{array}$ \\
\hline 23 & $\begin{array}{l}\text { Other non- } \\
\text { metallic min- } \\
\text { eral products }\end{array}$ & $\begin{array}{l}-0.004 \\
(0.004)\end{array}$ & $\begin{array}{l}-0.002 \\
(0.005)\end{array}$ & $\begin{array}{l}-0.001 \\
(0.004)\end{array}$ & $\begin{array}{l}-0.006 \\
(0.004)\end{array}$ & $\begin{array}{l}-0.004 \\
(0.004)\end{array}$ & $\begin{array}{l}-0.003 \\
(0.004)\end{array}$ \\
\hline 24 & Basic metals & $\begin{array}{c}0.001 \\
(0.004)\end{array}$ & $\begin{array}{c}0.029^{* * *} \\
(0.007)\end{array}$ & $\begin{array}{l}-0.005 \\
(0.010)\end{array}$ & $\begin{array}{l}-0.001 \\
(0.004)\end{array}$ & $\begin{array}{c}0.026^{* * *} \\
(0.007)\end{array}$ & $\begin{array}{l}-0.009 \\
(0.010)\end{array}$ \\
\hline
\end{tabular}

Notes: Standard errors are computed by employing the block bootstrap algorithm with 500 replications. *** denotes significance Research Data Centres of the Statistical Offices Germany (2014): Official Firm Data for Germany (AFiD) - Cost Structure Survey, AFiD-Panel Industrial Units, and AFiD-Module Use of Energy, own calculations.

Table 6: Difference-in-differences treatment effects - subsample analysis (II/II).

\begin{tabular}{|c|c|c|c|c|c|c|c|}
\hline \multirow[b]{2}{*}{ NACE } & \multirow[b]{2}{*}{ Industry } & \multicolumn{3}{|c|}{ III } & \multicolumn{3}{|c|}{ IV } \\
\hline & & $\begin{array}{c}\text { Pre- } \\
\text { treatment }\end{array}$ & Phase I & Phase II & $\begin{array}{c}\text { Pre- } \\
\text { treatment }\end{array}$ & Phase I & Phase II \\
\hline 10 & $\begin{array}{l}\text { Food prod- } \\
\text { ucts }\end{array}$ & $\begin{array}{c}0.022 \\
(0.018)\end{array}$ & $\begin{array}{l}0.004 \\
(0.010)\end{array}$ & $\begin{array}{c}0.006 \\
(0.011)\end{array}$ & $\begin{array}{c}0.021 \\
(0.017)\end{array}$ & $\begin{array}{l}0.012 \\
(0.009)\end{array}$ & $\begin{array}{l}0.008 \\
(0.010)\end{array}$ \\
\hline 17 & $\begin{array}{l}\text { Paper and pa- } \\
\text { per products }\end{array}$ & $\begin{array}{c}0.012 \\
(0.009)\end{array}$ & $\begin{array}{c}0.008 \\
(0.013)\end{array}$ & $\begin{array}{l}-0.006 \\
(0.014)\end{array}$ & $\begin{array}{c}0.013 \\
(0.009)\end{array}$ & $\begin{array}{c}0.012 \\
(0.013)\end{array}$ & $\begin{array}{l}-0.005 \\
(0.007)\end{array}$ \\
\hline 20 & $\begin{array}{l}\text { Chemicals and } \\
\text { chemical prod- } \\
\text { ucts }\end{array}$ & $\begin{array}{c}0.002 \\
(0.004)\end{array}$ & $\begin{array}{l}-0.001 \\
(0.006)\end{array}$ & $\begin{array}{c}0.003 \\
(0.006)\end{array}$ & $\begin{array}{c}0.001 \\
(0.004)\end{array}$ & $\begin{array}{c}0.001 \\
(0.006)\end{array}$ & $\begin{array}{c}0.005 \\
(0.007)\end{array}$ \\
\hline 22 & $\begin{array}{l}\text { Rubber and } \\
\text { plastic prod- } \\
\text { ucts }\end{array}$ & $\begin{array}{c}0.026^{* *} \\
(0.012)\end{array}$ & $\begin{array}{l}-0.002 \\
(0.007)\end{array}$ & $\begin{array}{c}0.004 \\
(0.006)\end{array}$ & $\begin{array}{l}0.020^{*} \\
(0.010)\end{array}$ & $\begin{array}{c}0.002 \\
(0.006)\end{array}$ & $\begin{array}{c}0.008 \\
(0.006)\end{array}$ \\
\hline 23 & $\begin{array}{l}\text { Other non- } \\
\text { metallic min- } \\
\text { eral products }\end{array}$ & $\begin{array}{l}-0.007 \\
(0.004)\end{array}$ & $\begin{array}{l}-0.004 \\
(0.005)\end{array}$ & $\begin{array}{l}-0.001 \\
(0.004)\end{array}$ & $\begin{array}{c}-0.007^{* *} \\
(0.004)\end{array}$ & $\begin{array}{c}0.002 \\
(0.004)\end{array}$ & $\begin{array}{l}-0.002 \\
(0.004)\end{array}$ \\
\hline 24 & Basic metals & $\begin{array}{c}0.002 \\
(0.004)\end{array}$ & $\begin{array}{c}0.025^{* * *} \\
(0.007)\end{array}$ & $\begin{array}{l}-0.011 \\
(0.010)\end{array}$ & $\begin{array}{l}-0.002 \\
(0.004)\end{array}$ & $\begin{array}{c}0.024^{* * *} \\
(0.008)\end{array}$ & $\begin{array}{l}-0.013 \\
(0.010)\end{array}$ \\
\hline
\end{tabular}

Notes: Standard errors are computed by employing the block bootstrap algorithm with 500 replications. *** denotes significance at the 99 percent level. ** denotes significance at the 95 percent level. * denotes significance at the 90 percent level. Source: Research Data Centres of the Statistical Offices Germany (2014): Official Firm Data for Germany (AFiD) - Cost Structure Survey,
AFiD-Panel Industrial Units, and AFiD-Module Use of Energy, own calculations. 


\subsection{Relaxing functional form assumptions}

The parametric difference-in-differences model described in Section 3.2 relies on functional form assumptions on the treatment and outcome model that might affect the estimated treatment effect. When including observable firm characteristics into the difference-in-differences model, I implicitly assume a linear relationship between the control variables, the treatment, and the outcome. In order to relax this assumption, I follow Fowlie, Holland, and Mansur (2012) and combine the difference-in-differences framework with nonparametric nearest neighbor matching. Based on the firm characteristics I observe, I match treated firms with similar untreated firms. The resulting control group only contains firms that are similar to the firms of the treatment group.

Following Heckman, Ichimura, and Todd (1997) and Heckman, Ichimura, Smith, and Todd (1998) the difference-in-difference matching estimator is described by

$$
\begin{aligned}
\hat{\tau}= & \frac{1}{N} \sum_{j \in I_{1}}\left\{\left(\ln (\text { Productivity })_{j t^{\prime}}(1)-\ln \left(\text { Productivity }_{j t^{0}}(0)\right)\right.\right. \\
& \left.-\sum_{k \in I_{0}} w_{j k}\left(\ln (\text { Productivity })_{k t^{\prime}}(0)-\ln (\text { Productivity })_{k t^{0}}(0)\right)\right\} .
\end{aligned}
$$

The set of firms regulated by the EU ETS is defined as $I_{1}$, while the unregulated firms are collected in set $I_{0}$. There are $N$ regulated firms indexed by $j$, the unregulated firms are indexed by $k$. The weight $w_{j k}$ takes the value one, if a firm of the control has been matched and zero otherwise. Following Fowlie, Holland, and Mansur (2012), I identify the nearest neighbor using the Mahalanobis distance to measure similarity between firms. I perform matching with replacement linking each treated firm with one and five similar firms of the control group. Similar firms are identified using information of the pretreatment year 2000 on output, capital stock, labor, energy use, material use as well as indicators for export and $\mathrm{R} \& \mathrm{D}$ experience. Due to the strong heterogeneity across industries, I exactly match on the two-digit industry classification.

Similarly to the parametric difference-in-differences approach, I assume that the mean productivities of treatment and control group evolve in a parallel fashion over time in the absence of the regulation by the EU ETS. In order to investigate the validity of this assumption, I conduct a pretreatment analysis using data from 1999 to 2002 with a placebo treatment in 2001.

Table 7 reports the results of the pretreatment analysis and the estimated treatment effects based on the difference-in-difference matching estimator. The estimates are based on a comparison between the pretreatment period from 2001 to 2002 with each compliance period of the EU ETS. I compute standard errors that are robust with respect to autocorrelation and heteroscedasticity following Abadie and Imbens (2006). The placebo treatment effects estimated for the year 2001 are close to zero and statistically insignificant. The treatment effect estimated for the first compliance period is statistically different from zero. When matching with the nearest neighbor, I obtain an average treatment effect of 2.7 percent. The preferred specification of the parametric difference-in-differences model provides a productivity increasing effect of 0.7 percent. 
Adding the five closest neighbors to the control group reduces the treatment effect to 1.5 percent. Also for the second compliance period, the nearest neighbor matching shows significantly positive estimates. The treatment effect ranges between 1.2 percent (one neighbor) and 1.4 (five neighbors). These results differ from the results of my main model that does not provide any evidence for a significant effect of the EU ETS during the second compliance period. These differing outcomes might be explained by the different designs of the two identification strategies. Applying the matching algorithm, I avoid the functional assumptions of the parametric difference-in-differences model and I only compare the regulated firms with very similar unregulated firms. Furthermore, I am only able to compare firms that stay in the sample during the considered time periods from 1999 to 2008 and from 1999 to 2012, respectively.

Apart from the average treatment effect for each compliance period, I also estimate annual treatment effects in order to investigate the development of the treatment effect over time. The pretreatment year 2000 serves as the base year for this approach. For the pretreatment years from 2001 to 2004, I expect the estimated treatment effects not to be statistically different from zero. Figure 3 shows the annual treatment effects and the corresponding confidence bands. From 2001 to 2004, the estimated treatment effect is not significantly different from zero. During the first compliance period, the confidence bands slightly widen, however the estimated treatment effects are statistically different from zero. During the first compliance period, the estimated treatment effect ranges between 1.4 percent (2006) and 3.8 percent (2007) when matching with the nearest neighbor and between 1.1 percent (2006) and 1.8 percent (2008) when matching with the five nearest neighbors. The estimated treatment effects for the second compliance period are closer to zero and statistically insignificant.

The results of the difference-in-differences nearest neighbor matching approach support the results of the parametric difference-in-differences model.

Table 7: Nonparametric difference-in-differences treatment effects.

\begin{tabular}{|c|c|c|c|}
\hline & $\begin{array}{c}\text { Pretreatment } \\
\text { analysis }\end{array}$ & Phase I & Phase II \\
\hline One neighbor & $\begin{array}{c}0.006 \\
(0.004)\end{array}$ & $\begin{array}{c}0.027^{* * *} \\
(0.009)\end{array}$ & $\begin{array}{l}0.012^{*} \\
(0.006)\end{array}$ \\
\hline Five neighbors & $\begin{array}{c}0.004 \\
(0.003)\end{array}$ & $\begin{array}{c}0.015^{* * *} \\
(0.005)\end{array}$ & $\begin{array}{c}0.014^{* * *} \\
(0.005)\end{array}$ \\
\hline \# Observations & 11,609 & 3,212 & 6,757 \\
\hline
\end{tabular}

Notes: The computed standard errors are based on Abadie and Imbens (2006). *** denotes significance at the 99 percent level. the Statistical Offices Germany (2014): Official Firm Data for Germany (AFiD) - Cost Structure Survey, AFiD-Panel Industrial Units, and AFiD-Module Use of Energy, own calculations. 
Figure 3: Annual treatment effects - NN matching.

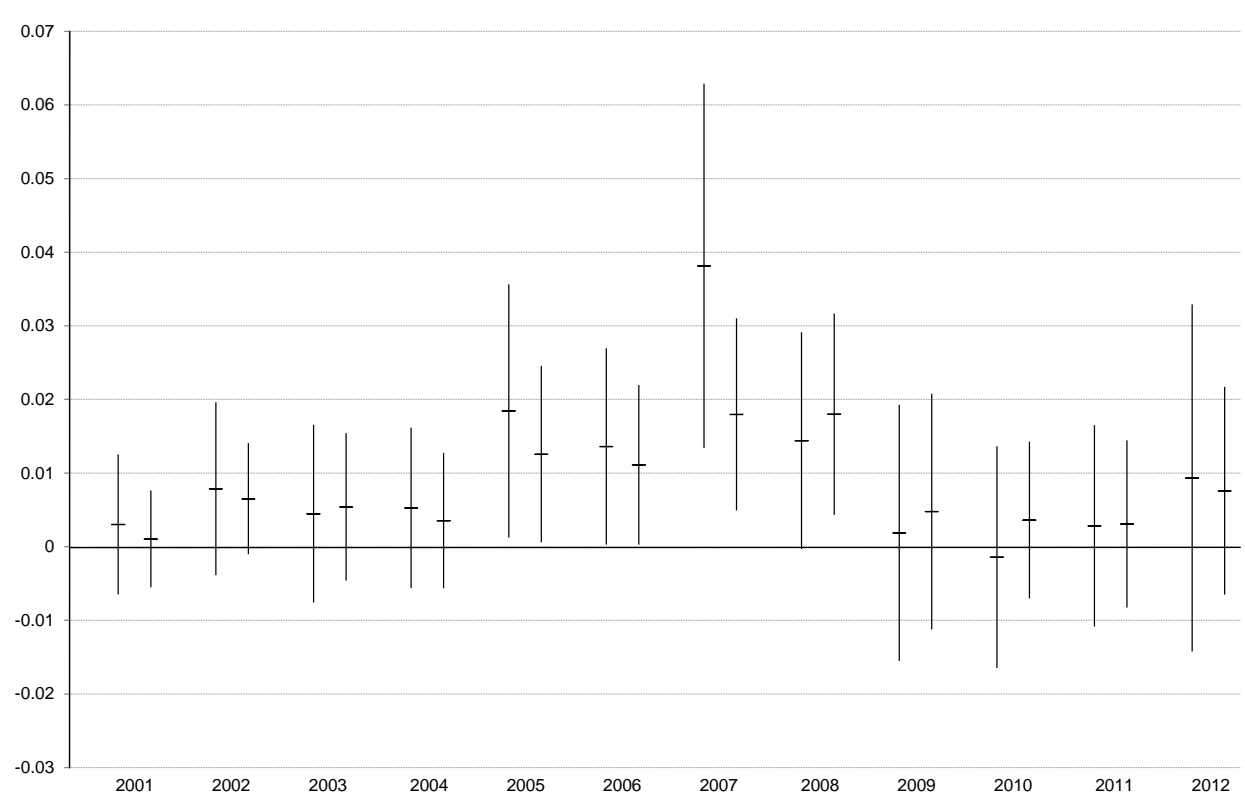

Notes: Annual treatment effects and confidence bands (2 times standard error) for nearest neighbor matching with one and five neighbors. As base year for the difference-in-difference approach serves the year 2000. The computed standard errors are based on Abadie and Imbens (2006). Source: Research Data Centres of the Statistical Offices Germany (2014): Official Firm Data for Germany (AFiD) - Cost Structure Survey and AFiD-Panel Industrial Units, own calculations.

\section{Concluding discussion}

Debates on potential detrimental effects of emissions trading on economic performance have accompanied the first two compliance periods of the EU ETS. This paper investigated the causal effect of the EU ETS on the total factor productivity of regulated firms. The productivity is measured as residual from a structural production function estimate that is robust with regard to endogeneity and allows the EU ETS to simultaneously influence input choice and the dynamic productivity process. I identify the effect of the EU ETS on firm-level productivity by exploiting treatment variation that occurs due to the design of the EU ETS. In order to releave small and medium sized emitters of carbon dioxide from the regulatory burden, only large emitters have been included into the EU ETS. I examine changes in the firm-level productivity by comparing regulated and unregulated firms before and after the implementation of the EU ETS. In particular, I estimate a variety of parametric difference-in-differences models including different sets of explanatory variables and fixed effects in order to eliminate the influence of potential confounding factors.

The estimated treatment effects for the first compliance period of the EU ETS are mostly statistically significant and positive. No effect of the EU ETS could be observed for the second compliance period using the parametric difference-in-differences model. Estimated treatment effects based on a combination of the difference-in-differences framework and nearest neighbor matching support the findings for the first compliance period, but also show a significant positive effect of the EU ETS on productivity during the sec- 
ond compliance period.

So far, there is no scientific study investigating the effect of the EU ETS on the total factor productivity of regulated firms. The very recent ex post evaluations of the EU ETS mostly find a significant reduction of carbon dioxide emissions (Petrick and Wagner, 2014; Wagner, Muûls, Martin, and Colmer, 2014; Klemetsen, Rosendahl, and Jakobsen, 2016) and emission intensity (Petrick and Wagner, 2014; Jaraitè and Di Maria, 2016) caused by the EU ETS. With regard to other firm characteristics, Petrick and Wagner, 2014 find a positive of the EU ETS on the revenue of German firms and Klemetsen, Rosendahl, and Jakobsen, 2016 find a positive effect on value added and labor productivity. Jaraite and Di Maria (2016) provide empirical evidence for a positive effect of the EU ETS on the renewal of installed capital stock. Wagner, Muûls, Martin, and Colmer, 2014 find that the EU ETS had a negative effect on employment. Calel and Dechezleprêtre (2016) investigate the effect of the EU ETS on patenting and find that it spurred low-carbon patents.

The results of this study are basically in line with these findings that are based on data from different European countries. Investments in more efficient capital stock triggered by the EU ETS could have reduced the use of static inputs such as energy and labor and thus might have increased the overall productivity. Innovative new products that require less energy use in the production process might have increased productivity and output as well.

There are several factors that might have influenced the analysis and should be kept in mind when discussing the results and their implications. First, I would like to point to the fact that the productivity measure employed in this study is revenue based. I use specific two-digit price indicators to deflate outputs produced and inputs employed, however there might be still changes driven by price developments. This has implications for the interpretation of the causal effect of the EU ETS. If firms are able to pass additional cost on to customers, then the higher output price due to a cost pass through could be reflected as a productivity gain. As shown by Bushnell, Chong, and Mansur (2012) and Fabra and Reguant (2014), emissions costs are passed through to electricity prices by utilities. It is likely that at least in some industries of the manufacturing sector firms are also able to pass through costs to product prices. A solution to this problem would be to estimate a quantity based productivity measure based on physical units of inputs and outputs. The estimation of a quantity based production function for multi-product firms is in general feasible (De Loecker, Goldberg, Khandelwal, and Pavcnik, 2016). However, this approach requires a sufficient number of single-product firms within narrowly defined industries. Using only German data, I do not observe enough single-product firms in order to estimate such a model.

A further issue that might influence the results of my analysis is the exit of firms caused by the EU ETS. If the EU ETS forced unproductive regulated firms out of the market, then the average productivity would increase in the group of the regulated firms even if the active firms remained on the same productivity level. Regrettably, 
the CSS is an unbalanced panel similar to the data sets used in many other studies of the productivity dispersion literature, such as Doraszelski and Jaumandreu (2013). The design of the CSS impedes a clear distinction between the exit from the market and the end of the obligation to participate in the survey. However, examining the EUTL data I do not observe significant attrition among the EU ETS regulated firms.

The second compliance period of the EU ETS coincides with the world economic crisis. In 2009, output produced and inputs employed decreased in the German manufacturing sector. Firms recovered quickly in the subsequent years, however consequences of the crisis might conflate with the effect of the EU ETS during the second compliance period. I assume that the crisis did not affect firms from the treatment and control group differently conditional on fixed effects and firm characteristics. Among other control variables, I include capital stock, employment, energy use, and material use into the difference-in-differences model in order to capture the variation caused by the crisis.

In this study, I focus on the direct effect of the EU ETS. I abstract from any indirect effects, e.g. through equilibrium effects or the increase of electricity prices due to the EU ETS.

Future research could tackle some of these issues. For example, one could investigate the effects of the EU ETS on industry dynamics by employing structural approaches to ideally European firm-level data.

\section{Acknowledgements}

I thank Andreas Löschel, Ulrich Wagner, Kathrine von Graevenitz, Claudio Baccianti, Maximilian Auffhammer and Sofia Berto Villas-Boas for suggestions and insightful comments. I am indebted to the Research Data Centre (FDZ) of the Federal Statistical Office and the Statistical Offices of the German Länder for granting me access to the AFiD data and for the use of their research facilities, in particular Michael Rößner for his advice and technical support at different stages of this research. I gratefully acknowledge the financial support of the Helmholtz Association through the Helmholtz Alliance ENERGY-TRANS and the Helmholtz scholarship that enabled me to visit the Department of Agricultural and Resource Economics at the University of California, Berkeley, where this paper was written. Further, I would like to thank the Department of Agricultural and Resource Economics for its hospitality - especially my host during the stay, Maximilian Auffhammer. Thorsten Doherr and Tobias Krabel provided excellent research assistance. The views expressed in this paper are those of the author and do not necessarily represent those of the ZEW or the FDZ.

\section{References}

Abadie, A., and G. W. Imbens (2006): "Large Sample Properties of Matching Estimators for Average Treatment Effects," Econometrica, 74(1), 235-267. 
Ackerberg, D., C. L. Benkard, S. Berry, and A. Pakes (2007): "Econometric Tools for Analyzing Market Outcomes," Handbook of econometrics, 6, 4171-4276.

Ackerberg, D., K. Caves, and G. Frazer (2015): "Identification Properties of Recent Production Function Estimators," Econometrica, 83(6), 2411-2451.

Aw, B. Y., M. J. Roberts, And D. Y. XU (2011): "R\&D Investment, Exporting, and Productivity Dynamics," American Economic Review, 101(4), 1312-1344.

Bertrand, M., E. Duflo, and S. Mullainathan (2004): "How Much Should We Trust Differences-In-Differences Estimates?," The Quarterly Journal of Economics, $119(1), 249-275$.

Bloom, N., and J. Van Reenen (2007): "Measuring and Explaining Management Practices Across Firms and Countries," The Quarterly Journal of Economics, 122(4), 1351-1408.

Braguinsky, S., A. Ohyama, T. Okazaki, and C. Syverson (2015): "Acquisitions, Productivity, and Profitability: Evidence from the Japanese Cotton Spinning Industry," The American Economic Review, 105(7), 2086-2119.

Bushnell, J. B., H. Chong, and E. T. Mansur (2013): "Profiting from regulation: Evidence from the European carbon market," American Economic Journal: Economic Policy, 5(4), 78-106.

Calel, R., and A. Dechezlepretre (2016): "Environmental policy and directed technological change: evidence from the European carbon market," Review of Economics and Statistics, (00).

Collard-Wexler, A., And J. De Loecker (2015): "Reallocation and Technology: Evidence from the US Steel Industry," The American Economic Review, 105(1), 131171.

Commins, N., S. Lyons, M. Schiffbauer, and R. S. Tol (2011): "Climate policy and corporate behaviour," Energy Journal, 32(4), 51-63.

Criscuolo, C., and R. Martin (2009): "Multinationals and U.S. Productivity Leadership: Evidence from Great Britain," Review of Economics and Statistics, 91(2), $263-281$.

De Loecker, J. (2007): "Do Exports Generate Higher Productivity? Evidence from Slovenia," Journal of International Economics, 73(1), 69-98.

(2013): "Detecting Learning by Exporting," American Economic Journal: Microeconomics, 5(3), 1-21.

De Loecker, J., P. K. Goldberg, A. K. Khandelwal, and N. Pavcnik (2016): "Prices, Markups, and Trade Reform," Econometrica, 84(2), 445-510. 
De Loecker, J., and F. Warzynski (2012): "Markups and Firm-Level Export Status," The American Economic Review, 102(6), 2437-2471.

Doraszelski, U., And J. Jaumandreu (2013): "R\& D and Productivity: Estimating Endogenous Productivity," Review of Economic Studies, 80(4), 1338-1383.

European Parliament And Council (2003): "Directive 2003/87/EC of the European Parliament and of the Council of 13 October 2003 establishing a scheme for greenhouse gas emission allowance trading within the Community and amending Council Directive 96/61/EC," Official Journal of the European Union, L 275, 32-46.

Fabra, N., And M. Reguant (2014): "Pass-through of emissions costs in electricity markets," The American Economic Review, 104(9), 2872-2899.

Fowlie, M., S. P. Holland, and E. T. Mansur (2012): "What Do Emissions Markets Deliver and to Whom? Evidence from Southern California's NOx Trading Program," American Economic Review, 102(2), 965-93.

Greenstone, M., J. A. List, and C. Syverson (2012): "The effects of environmental regulation on the competitiveness of US manufacturing," National Bureau of Economic Research Working Paper No. 18392.

Hall, B. H., And J. Mairesse (1995): "Exploring the relationship between R\&D and productivity in French manufacturing firms," Journal of Econometrics, 65(1), $263-293$.

Heckman, J., H. Ichimura, J. Smith, and P. Todd (1998): "Characterizing selection bias using experimental data," Econometrica, 66(5), 1017-1098.

Heckman, J. J., H. Ichimura, and P. E. Todd (1997): "Matching as an econometric evaluation estimator: Evidence from evaluating a job training programme," The Review of Economic Studies, 64(4), 605-654.

Hicks, J. R. (1932): The Theory of Wages. Macmillan, New York.

Horowitz, J. (2001): "The Bootstrap," in Handbook of Econometrics, ed. by J. J. Heckman, and E. Learner, vol. 5, pp. 3159-3228. Elsevier Science, Oxford.

Jaraité, J., And C. Di Maria (2016): "Did the EU ETS Make a Difference? An Empirical Assessment Using Lithuanian Firm-Level Data," The Energy Journal, 37(1), $1-23$.

Klemetsen, M. E., K. E. Rosendahl, and A. L. Jakobsen (2016): "The impacts of the EU ETS on Norwegian plants' environmental and economic performance," NMBU Working Papers 3/2016. Available at https://www.nmbu.no/sites/default/files/pdfattachments/hh_wp_3_2016_0.pdf. 
Knittel, C. R. (2002): "Alternative Regulatory Methods and Firm Efficiency: Stochastic Frontier Evidence from the U.S. Electricity Industry," Review of Economics and Statistics, 84(3), 530-540.

Levinsohn, J., and A. Petrin (2003): "Estimating Production Functions Using Inputs to Control for Unobservables," The Review of Economic Studies, 70(2), 317-341.

Marschak, J., and W. H. Andrews (1944): "Random Simultaneous Equations and the Theory of Production," Econometrica, 12(3-4), 143-205.

Olley, G. S., And A. Pakes (1996): "The Dynamics of Productivity in the Telecommunications Equipment Industry," Econometrica, 64(6), 1263-1297.

Petrick, S., And U. Wagner (2014): "The Impact of Carbon Trading on Industry: Evidence from German Manufacturing Firms," Available at SSRN: http://papers.ssrn.com/sol3/papers.cfm?abstract_id=2389800.

Porter, M. E. (1991): “America's green strategy.," Scientific American, 264(4), 168.

Porter, M. E., And C. VAn Der Linde (1995): "Toward a new conception of the environment competitiveness relationship.," Journal of Economic Perspectives, 9(4), $97-118$.

Research Data Centres of the Statistical Offices Germany (2014): "AFiDPanel Industrial Units, AFiD-Module Use of Energy, and Cost Structure Survey 19952010," Further information: http://www.forschungsdatenzentrum.de/en/index.asp.

Syverson, C. (2011): "What Determines Productivity?, Journal of Economic Literature, 49(2), 326-365.

The Federation of German Industries (2016): "CO2-Preis setzt Wettbewerbsähigkeit eruopäischer Industrien zusätzlich unter Druck - CO2 price puts competitiveness of European industry under pressure," Available at http://bdi.eu/artikel/news/co2-preis-setzt-wettbewerbsfaehigkeit-europaeischerindustrien-zusaetzlich-unter-druck/.

van Biesebroeck, J. (2003): "Productivity Dynamics with Technology Choice: An Application to Automobile Assembly," The Review of Economic Studies, 70(1), 167198.

Wagner, U. J., M. Mû̂ls, R. Martin, and J. Colmer (2014): "The Causal Effects of the European Union Emissions Trading Scheme: Evidence from French Manufacturing Plants," Mimeo. 


\section{Appendix A. Additional information on data and descrip- tive statistics}

\section{A.1. EUA price development}

Appendix A.1. provides additional information on the EUA price development. Figure 4 shows the price series of the ICE-ECX EUA front year futures with the closest maturity.

Figure 4: EUA prices 2005 - 2013

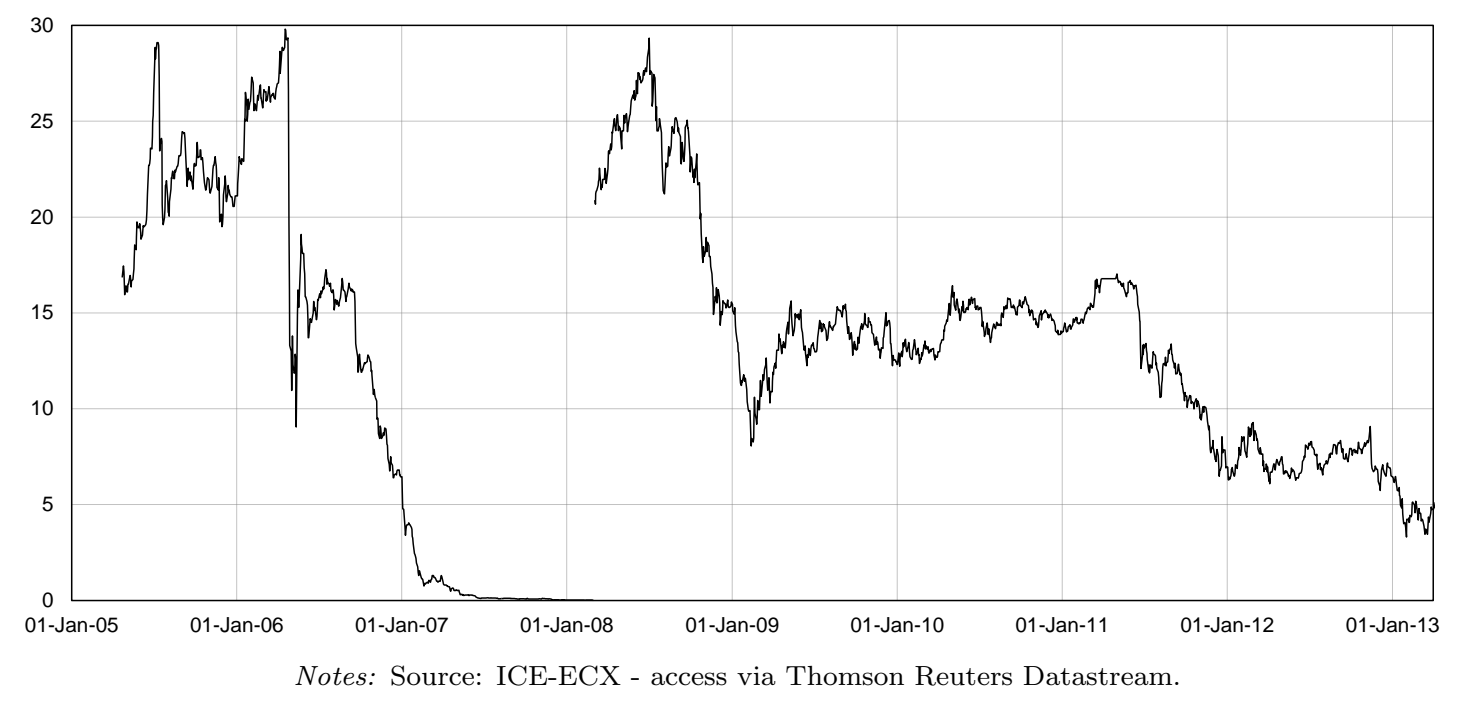




\section{A.2. Free allocation and verified emissions}

Appendix A.2. provides information on the free allocation and the verified emissions of firms in the dataset. Table 8 shows the total amount of grandfathered EUAs and the total amount of verified emissions for two digit industries.

Table 8: Number of observations by industry: total and regulated firms

\begin{tabular}{|c|c|c|c|c|c|c|c|}
\hline \multirow[b]{2}{*}{ NACE } & \multirow[b]{2}{*}{ Industry } & \multicolumn{3}{|c|}{ Phase I } & \multicolumn{3}{|c|}{ Phase II } \\
\hline & & $\begin{array}{l}\text { Free al- } \\
\text { location }\end{array}$ & $\begin{array}{l}\text { Verified } \\
\text { emis- } \\
\text { sions } \\
\end{array}$ & Balance & $\begin{array}{l}\text { Free al- } \\
\text { location }\end{array}$ & $\begin{array}{l}\text { Verified } \\
\text { emis- } \\
\text { sions } \\
\end{array}$ & Balance \\
\hline 10 & Food products & $10,730.32$ & $9,695.56$ & $1,034.76$ & $21,471.65$ & 18037.63 & 3434.02 \\
\hline 11 & Beverages & 448.38 & 446.22 & 2.16 & 862.98 & 718.35 & 144.63 \\
\hline 12 & Tobacco products & . & $\cdot$ & . & $\cdot$ & . & $\cdot$ \\
\hline 13 & Textiles & . & . & . & . & . & . \\
\hline 14 & Wearing apparel & 0 & 0 & 0 & 0 & 0 & 0 \\
\hline 15 & $\begin{array}{l}\text { Leather and } \\
\text { related products }\end{array}$ & 0 & 0 & 0 & 0 & 0 & 0 \\
\hline 16 & $\begin{array}{l}\text { Wood and prod- } \\
\text { ucts of wood and } \\
\text { cork }\end{array}$ & $1,805.56$ & 575.27 & $1,230.29$ & $5,320.81$ & $1,029.93$ & $4,290.88$ \\
\hline 17 & $\begin{array}{l}\text { Paper and paper } \\
\text { products }\end{array}$ & $21,398.24$ & $17,597.27$ & $3,800.97$ & $36,300.12$ & $26,661.00$ & $9,638.12$ \\
\hline 18 & $\begin{array}{l}\text { Printing and } \\
\text { reproduction of } \\
\text { recorded media }\end{array}$ & $\cdot$ & $\cdot$ & $\cdot$ & $\cdot$ & $\cdot$ & $\cdot$ \\
\hline 19 & $\begin{array}{l}\text { Coke and refined } \\
\text { petroleum prod- } \\
\text { ucts }\end{array}$ & $77,947.19$ & $77,925.31$ & 21.88 & $134,922.3$ & $124,959.69$ & $9,962.61$ \\
\hline 20 & $\begin{array}{l}\text { Chemicals and } \\
\text { chemical prod- } \\
\text { ucts }\end{array}$ & $38,861.04$ & $30,589.69$ & $8,271.35$ & $10,1483.09$ & $87,533.43$ & $13,949.66$ \\
\hline 21 & $\begin{array}{l}\text { Pharmaceutical } \\
\text { products }\end{array}$ & $2,276.38$ & $1,390.66$ & 885.73 & $3,108.41$ & $2,040.37$ & $1,068.03$ \\
\hline 22 & $\begin{array}{l}\text { Rubber and plas- } \\
\text { tic products }\end{array}$ & $1,130.28$ & $1,000.44$ & 129.85 & $1,775.60$ & $1,463.27$ & 312.34 \\
\hline 23 & $\begin{array}{l}\text { Other non- } \\
\text { metallic mineral } \\
\text { products }\end{array}$ & $90,831.29$ & $79,230.95$ & $11,600.34$ & $156,617.63$ & $137,016.66$ & $19,600.97$ \\
\hline 24 & Basic metals & $112,048.83$ & $101,291.07$ & $10,757.76$ & $264,550.73$ & $164,814.81$ & $99,735.92$ \\
\hline 25 & $\begin{array}{l}\text { Fabricated metal } \\
\text { products }\end{array}$ & $\cdot$ & $\cdot$ & $\cdot$ & $\cdot$ & $\cdot$ & $\cdot$ \\
\hline 26 & $\begin{array}{l}\text { Computer, elec- } \\
\text { tronic and optical } \\
\text { products }\end{array}$ & $\cdot$ & $\cdot$ & $\cdot$ & $\cdot$ & $\cdot$ & $\cdot$ \\
\hline 27 & $\begin{array}{l}\text { Electrical equip- } \\
\text { ment }\end{array}$ & $\cdot$ & $\cdot$ & $\cdot$ & $\cdot$ & $\cdot$ & $\cdot$ \\
\hline 28 & $\begin{array}{l}\text { Machinery and } \\
\text { equipment n.e.c. }\end{array}$ & $\cdot$ & $\cdot$ & . & $\cdot$ & $\cdot$ & $\cdot$ \\
\hline 29 & $\begin{array}{l}\text { Motor vehicles, } \\
\text { trailers, and } \\
\text { semi-trailers }\end{array}$ & $8,853.423$ & $8,154.973$ & 698.45 & $12,476.513$ & $14,623.63$ & $-2,147.117$ \\
\hline 30 & $\begin{array}{l}\text { Other transport } \\
\text { equipment }\end{array}$ & $\cdot$ & $\cdot$ & $\cdot$ & . & . & $\cdot$ \\
\hline 31 & Furniture & 0 & 0 & 0 & 0 & 0 & 0 \\
\hline 32 & $\begin{array}{l}\text { Other manufac- } \\
\text { turing }\end{array}$ & $\cdot$ & . & · & $\cdot$ & $\cdot$ & $\cdot$ \\
\hline 33 & $\begin{array}{l}\text { Repair and instal- } \\
\text { lation of mach. } \\
\text { and equip. }\end{array}$ & $\cdot$ & $\cdot$ & $\cdot$ & $\cdot$ & $\cdot$ & $\cdot$ \\
\hline
\end{tabular}

Notes: . marks statistics that have not been released by the statistical offices due to the low number of observations. Source: Research Data Centres of the Statistical Offices Germany (2014): Official Firm Data for Germany (AFiD) - Cost Structure Survey and AFiD-Panel Industrial Units, own calculations. 


\section{A.3. Matching AFiD, CSS, and EUTL}

The different internal data sets of the Statistical Offices Germany, such as AFiD and CSS, can be easily merged via plant and firm-level indentifiers. However, it requires some effort to match external data to AFiD and CSS, since the information on firm identifiers and names is not accessible for researchers. I match AFiD data on the firm-level with aggregated data from the EUTL for the years from 2005 to 2012 using the commercial register number and the VAT number. I am able to match 77 percent ( 813 firms) of the firms in the EUTL with AFiD. The 238 firms that are not matched mainly belong to the energy, public, or service sector and thus are not contained in the production census for manufacturing. 


\section{A.4. Descriptive statistics - full sample}

Table 9 reports additional descriptive statistics on the full sample.

Table 9: Additional descriptive statistics

\begin{tabular}{|c|c|c|c|c|c|c|c|c|}
\hline & Mean & SD & Skewn & Kurtosis & p10 & $\mathrm{p} 50$ & p90 & $\mathrm{N}$ \\
\hline \multicolumn{9}{|l|}{2000} \\
\hline Gross value added & $24,969.77$ & $233,803.09$ & 34.88 & $1,436.37$ & $1,111.46$ & $4,473.50$ & $36,967.21$ & 15,107 \\
\hline Output & $58,790.54$ & $548,088.98$ & 48.64 & $3,017.09$ & $2,077.68$ & $10,260.49$ & $96,753.55$ & 14,998 \\
\hline Capital stock & $21,722.82$ & $176,689.16$ & 33.88 & $1,380.38$ & 455.93 & $3,545.52$ & $34,412.70$ & 15,039 \\
\hline Wages and salaries & $12,995.41$ & $116,283.62$ & 47.35 & $2,665.08$ & 797.66 & $2,868.15$ & $22,520.11$ & 15,106 \\
\hline Energy use & $46,893.63$ & $803,001.62$ & 60.14 & $4,767.93$ & 164.10 & $1,660.84$ & $30,951.67$ & 15,106 \\
\hline Number of employees & 294.68 & $2,093.58$ & 45.16 & $2,458.74$ & 27.75 & 85.67 & 547.83 & 15,106 \\
\hline $\mathrm{R} \& \mathrm{D}$ expenditure & $2,392.66$ & $52,273.32$ & 48.67 & $2,686.61$ & 0 & 0 & 975.5043 & 15,107 \\
\hline Exports & $30,226.70$ & $459,974.70$ & 49.82 & $2,919.78$ & 0 & $1,111.121$ & $35,350.72$ & 15,106 \\
\hline \multicolumn{9}{|l|}{2005} \\
\hline Gross value added & $27,345.33$ & $266,307.21$ & 39.93 & $2,011.60$ & $1,173.94$ & $4,987.07$ & $39,760.41$ & 13,858 \\
\hline Output & $68,637.96$ & $646,894.49$ & 49.06 & $2,956.55$ & $2,287.86$ & $11,930.16$ & $110,994.73$ & 13,604 \\
\hline Capital stock & $23,445.80$ & $198,335.76$ & 38.00 & $1,769.07$ & 480.71 & $3,605.26$ & $36,694.26$ & 13,772 \\
\hline Wages and salaries & $13,293.17$ & $118,987.17$ & 46.27 & $2,522.02$ & 771.88 & $2,957.47$ & $22,089.02$ & 13,857 \\
\hline Energy use & $55,565.39$ & $793,966.15$ & 42.11 & $2,313.17$ & 275.40 & $2,135.74$ & $36,675.84$ & 13,669 \\
\hline Number of employees & 296.61 & $2,106.77$ & 44.87 & $2,419.63$ & 28.25 & 88.92 & 531.25 & 13,857 \\
\hline $\mathrm{R} \& \mathrm{D}$ expenditure & $3,082.25$ & $62,091.20$ & 44.90 & $2,293.96$ & 0 & 0 & $1,541.87$ & 13,858 \\
\hline Exports & $39,977.06$ & $560,038.10$ & 46.71 & $2,517.40$ & 0 & $2,106.06$ & $48,757.09$ & 13,857 \\
\hline \multicolumn{9}{|l|}{2010} \\
\hline Gross value added & $25,483.97$ & $269,640.70$ & 39.65 & $1,836.76$ & $1,149.20$ & $4,582.03$ & $34,591.33$ & 15,399 \\
\hline Output & $66,443.37$ & $709,260.71$ & 57.04 & $3,867.12$ & $2,309.90$ & $11,687.90$ & $106,083.33$ & 15,250 \\
\hline Capital stock & $21,201.18$ & $179,555.17$ & 39.14 & $1,909.50$ & 451.18 & $3,404.83$ & $33,839.90$ & 15,324 \\
\hline Wages and salaries & $11,785.77$ & $105,233.78$ & 47.18 & $2,613.07$ & 749.72 & $2,679.64$ & $19,384.89$ & 15,385 \\
\hline Energy use & $62,728.99$ & $1,144,134.97$ & 51.02 & $3,124.93$ & 294.94 & $2,136.16$ & $35,485.39$ & 15,258 \\
\hline Number of employees & 269.29 & $1,887.62$ & 46.79 & $2,628.07$ & 30.00 & 85.08 & 479.58 & 15,384 \\
\hline$R \& D$ expenditure & $2,878.184$ & $60,147.87$ & 46.24 & $2,480.41$ & 0 & 0 & $1,389.11$ & 15,399 \\
\hline Exports & $40,749.75$ & 639149.50 & 50.55 & 2918.14 & 0 & $2,050.15$ & $48,962.84$ & 15,385 \\
\hline
\end{tabular}

Notes: Gross value added, output (production value), wages and salaries, R\&D expenditure, exports and capital stock are denoted in EUR 1000. Energy use is denoted in MWh. Source: Research Data Centres of the Statistical Offices Germany (2014): Official Firm Data for Germany (AFiD) - Cost Structure Survey, AFiD-Panel Industrial Units, and AFiD-Module Use of Energy, own calculations. 


\section{Appendix B. Capital stocks for the German production cen-} sus

Information on capital stocks is an important ingredient for several applications in empirical economic research - especially productivity analysis. The official production census of the German manufacturing sector (Amtliche Firmendaten für Deutschland; AFiD) comprises rich information on investments on the plant and the firm-level, but does not include information on capital stocks. In order to remedy this shortcoming, I compute capital stocks employing the perpetual inventory method (PIM).

The basic formula of the perpetual inventory method is

$$
K_{t}=K_{t-1}(1-\delta)+I_{t}
$$

where $K$ denotes capital stock, $\delta$ the geometric depreciation rate and $I$ the investment. From the basic formula one can derive the initial capital stock $K_{1}$.

$$
\begin{gathered}
K_{1}=I_{0}+I_{-1}(1-\delta)+I_{-2}(1-\delta)^{2}+\ldots \\
K_{1}=\sum_{s=0}^{\infty} I_{s}(1-\delta)^{s}
\end{gathered}
$$

I follow a notation that has been also used by earlier empirical studies as for instance Hall and Mairesse (1995). I assume the real investments to grow by the rate g.

$$
\begin{gathered}
K_{1}=I_{0} \sum_{s=0}^{\infty}\left[\frac{(1-\delta)}{(1+g)}\right]^{s} \\
K_{1}=I_{0} \frac{(1+g)}{(g+\delta)}
\end{gathered}
$$

Hence, the capital at the beginning of the first period is defined by

$$
K_{1}=I_{1} \frac{1}{(g+\delta)}
$$

The PIM has been extensively used in studies that analyze sector and country level data. In principle, it also can be applied for the computation of capital stocks based on micro level data. However, turning from aggregate data toward micro data creates some issues that have to be considered: First, investments are lumpy, i.e. investments highly fluctuate over time. This property of investments on firm and plant level creates difficulties to compute the initial capital stocks. Considering this, I compute the average of $I_{t}$ over all time periods available in order to estimate $I_{1}$.

$$
\hat{I_{1}}=\frac{\sum_{t=0}^{n} \frac{I_{t+1}}{(1+i)^{t}}}{n}
$$

This leads us to the second issue that has to be considered when applying the PIM on micro data: It requires the observation of single agents (plants, firms, etc) over several 
time periods. For AFiD this issue is not a problem, since the investment data is census data. The resulting data set is a panel giving information for each year from 1995 to 2012. Otherwise it would be problematic to compute the initial capital stock. The growth rate of capital $g$ and the depreciation rate $\delta$ can either be assumed to take a certain value or it can be estimated for each industry based on aggregate data. I follow the latter approach and use aggregated data on the two-digit industry level and compute industry specific average growth rates and depreciation rates.

In order to estimate the capital stock I use the firm-level investment data from the AFiD-Panel Industrial Units comprising investment in machinery and equipment, investment in buildings, and investment in properts without buildings. I deflate the investments using two-digit industry level deflators for machinery and equipment as well as general deflators for buildings and property without buildings. Starting from $K_{1}$ I plug the firm specific investments and the industry specific time-varying depreciation rates into equation 13 in order to compute the entire time series of the firm's capital stock.

Apart from the AFiD-Panel Industrial Units, I exploit aggregate data on the twodigit industry level. These aggregate data can be retrieved via the Destatis portal GENESIS ${ }^{17}$ In particular I used the tables 81000-0107 National Accounts Depreciation, 81000-0115 Gross Investment, 81000-0116 Gross Capital Stock, 81000-0117 Net Capital Stock, and 61262-0001 Price Index Property in order to compute the growth rates, the depreciation rates and the deflators.

Since the focus of this study lies on the firm-level, I compute the capital stocks for firms. The method can be also employed to estimate capital stocks on the plant level. Table 10 reports descriptive statistics of the capital stock for firms in my sample.

\footnotetext{
${ }^{17}$ https://www-genesis.destatis.de/genesis/online
} 
Table 10: Descriptive statistics capital stock

\begin{tabular}{ccccccccc}
\hline \hline & Mean & SD & Skewn & Kurtosis & p10 & p50 & p90 & N \\
\hline 1999 & $21,146.23$ & $172,173.5$ & 34.12 & $1,386.98$ & 445.00 & $3,496.39$ & $33,492.84$ & 15,125 \\
2000 & $21,722.82$ & $176,689.2$ & 33.88 & $1,380.38$ & 455.93 & $3,545.52$ & $34,412.70$ & 15,039 \\
2001 & $23,070.89$ & $183,951.9$ & 32.97 & $1,307.05$ & 483.09 & $3,742.21$ & $36,520.37$ & 14,193 \\
2002 & $23,910.89$ & $190,909.2$ & 32.59 & $1,269.70$ & 498.21 & $3,867.37$ & $37,574.70$ & 13,603 \\
2003 & $23,476.19$ & $191,567.4$ & 34.13 & $1,401.42$ & 474.83 & $3,648.04$ & $36,643.93$ & 14,460 \\
2004 & $23,071.02$ & $191,259.8$ & 37.10 & $1,684.88$ & 472.18 & $3,574.86$ & $36,549.22$ & 14,270 \\
2005 & $23,445.8$ & $198,335.8$ & 38.00 & $1,769.07$ & 480.71 & $3,605.26$ & $36,694.26$ & 13,772 \\
2006 & $23,777.36$ & $197,148.1$ & 37.34 & $1,719.16$ & 484.33 & $3,666.73$ & $37,776.86$ & 13,405 \\
2007 & $23,906.36$ & $194,193.5$ & 36.75 & $1,676.67$ & 484.88 & $3,725.18$ & $38,495.00$ & 13,161 \\
2008 & $20,665.96$ & $174,540.6$ & 40.26 & $2,021.59$ & 450.68 & $3,340.48$ & $33,742.33$ & 16,088 \\
2009 & $21,412.52$ & $180,442.9$ & 40.08 & $2,011.87$ & 454.33 & $3,440.60$ & $34,780.25$ & 15,714 \\
2010 & $21,201.18$ & $179,555.2$ & 39.14 & $1,909.50$ & 451.18 & $3,404.83$ & $33,839.90$ & 15,324 \\
2011 & $21,480.04$ & $184,980.6$ & 37.12 & $1,736.09$ & 448.65 & $3,402.04$ & $32,790.13$ & 14,965 \\
2012 & $21,393.36$ & $189,500.1$ & 37.90 & $1,795.70$ & 433.42 & $3,146.24$ & $33,135.09$ & 14,926 \\
\hline
\end{tabular}

Notes: Gross value added, output (production value), wages and salaries, R\&D expenditure, exports and capital stock are denoted in EUR 1000. Energy use is denoted in MWh. Source: Research Data Centres of the Statistical Offices Germany (2014): Official Firm Data for Germany (AFiD) - Cost Structure Survey, AFiD-Panel Industrial Units, and AFiD-Module Use of Energy, own calculations. 